\title{
Combinatoric innovation : environments for creation and mobilization of intellectual capital
}

Citation for published version (APA):

Iske, P. L. (2010). Combinatoric innovation : environments for creation and mobilization of intellectual capital. Maastricht University. https://doi.org/10.26481/spe.20101105pi

Document status and date:

Published: 05/11/2010

DOI:

$10.26481 /$ spe.20101105pi

Document Version:

Publisher's PDF, also known as Version of record

\section{Please check the document version of this publication:}

- A submitted manuscript is the version of the article upon submission and before peer-review. There can be important differences between the submitted version and the official published version of record.

People interested in the research are advised to contact the author for the final version of the publication, or visit the DOI to the publisher's website.

- The final author version and the galley proof are versions of the publication after peer review.

- The final published version features the final layout of the paper including the volume, issue and page numbers.

Link to publication

\footnotetext{
General rights rights.

- You may freely distribute the URL identifying the publication in the public portal. please follow below link for the End User Agreement:

www.umlib.nl/taverne-license

Take down policy

If you believe that this document breaches copyright please contact us at:

repository@maastrichtuniversity.nl

providing details and we will investigate your claim.
}

Copyright and moral rights for the publications made accessible in the public portal are retained by the authors and/or other copyright owners and it is a condition of accessing publications that users recognise and abide by the legal requirements associated with these

- Users may download and print one copy of any publication from the public portal for the purpose of private study or research.

- You may not further distribute the material or use it for any profit-making activity or commercial gain

If the publication is distributed under the terms of Article $25 \mathrm{fa}$ of the Dutch Copyright Act, indicated by the "Taverne" license above, 


\section{Maastricht University}

Paul Louis Iske

School of Business and Economics

Combinatoric Innovation

Environments for creation and mobilization of intellectual capital

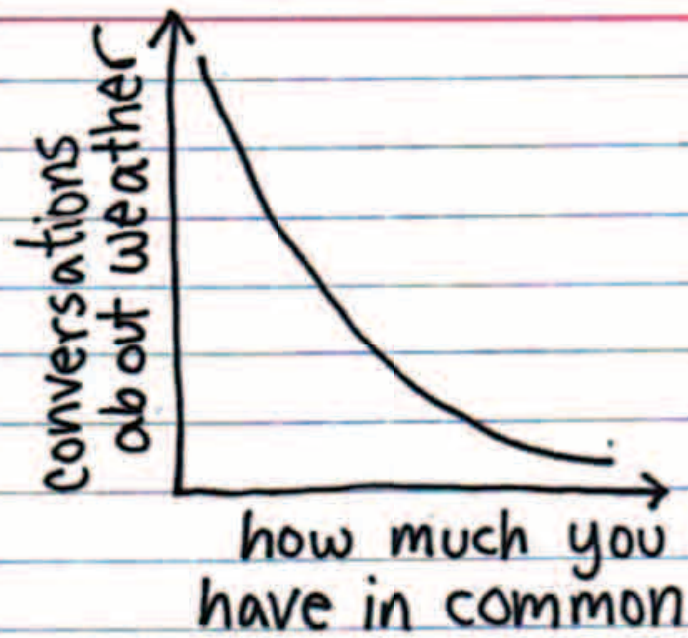


Combinatoric Innovation

Environments for creation and mobilization

of intellectual capital 


\section{Colofon}

Ontwerp en print: Océ Business Services, Maastricht

ISBN: 978-905-681-347-5

NUR: 781

Alle rechten voorbehouden. Niets uit deze uitgave mag worden verveelvoudigd, opgeslagen in een geautomatiseerd gegevensbestand of openbaar gemaakt worden, zonder voorafgaande schriftelijke toestemming van de auteur of uitgever. 


\section{Combinatoric Innovation}

\section{Environments for creation and mobilization of intellectual capital}

Inaugural Lecture

Maastricht, 5 november 2010

Paul Louis Iske 
Mijnheer de rector magnificus, geachte collega's en overige aanwezigen, Veel van wat wij zien en beleven is het gevolg van een samenloop van omstandigheden. Toen ik eind 1989 promoveerde in de theoretische fysica, kon ik moeilijk vermoeden dat ik ruim twintig jaar later benoemd zou worden tot praktijkhoogleraar aan de School of Business en Economics aan deze mooie universiteit. Ik heb niet eens economieles gehad op de middelbare school. Maar in die postdoctorale periode heb ik in veel verschillende omgevingen gewerkt en geadviseerd en heb daarbij een passie ontwikkeld voor het slaan van bruggen en toepassen van kennis op andere plekken dan waar die oorspronkelijk is ontstaan. En zo groeide ook bij mij, zeker niet van a tot z gepland, een unieke combinatie van kennis die er uiteindelijk toe heeft geleid dat ik vandaag hier mag staan.

The world we live in is becoming increasingly complex and is changing at an ever-faster pace. Understanding complex adaptive systems is critical to addressing the key environmental, technological, biological, economic, and political challenges of our time. In our economies new drivers of value are emerging and new companies are being established and others are going out of business, both at unprecedented rates. In the economy as a whole, and in particular in the service sector which can be seen as a complex adaptive system, there is increasing realization that the ability to create and mobilize intellectual capital lies behind many of these new drivers of value. Whilst there are examples of companies that seem to 'intuitively' capitalize on this ability, our understanding of and toolbox for growing and leveraging this ability is still in its infancy.

One tool for creating and mobilizing intellectual capital is 'Combinatoric Innovation', and this is the core subject of my speech today. The central idea is that it 'pays off' to create the conditions under which parties with diverse backgrounds can combine their knowledge to find new ways for value creation. The term Combinatoric Innovation has been coined for describing this process, which is characterized by combination, trial \& error, and learning. Combinatoric Innovation is non-linear and thus by nature unpredictable and uncontrollable. However, this does not imply that the chance of success and the efficiency of this process cannot be positively influenced by developing and applying knowledge in relevant areas.

In particular, I would like to introduce you to a framework for studying and developing environments that inspire and facilitate Combinatoric 
Innovation. Here, we define an environment as the interplay between the process and the social, physical and virtual spaces that have an influence on human and organizational behavior and performance. One of the most important findings about environments for Combinatoric Innovation that I would like to share is: "If they use it, it will build itself!"

\section{Can mountains move?}

Let's explore a well-known, historic problem, which is that Muhammad won't come to the mountain. The classical solution is that the mountain must come to Muhammad. However, there might be other ways of solving the problem: Lateral thinking has been defined by Edward the Bono as a technique for problem solving by approaching problems indirectly from diverse angles instead of concentrating on one approach from a single perspective at length. In lateral thinking, the expression 'PO', which stands for Provocative Operation, is used to propose an idea which may not necessarily be a solution or a 'good' idea in itself, but moves thinking forward to a new place where new ideas can be produced. By using this approach, the following solutions for the problem of Muhammad and the mountain could be derived:

PO: Use a video conference: an ICT-driven solution

PO: Use an intermediary: probably proposed by a social scientist

PO: Ask him what he 'needs' to come to the mountain: the perspective of a diplomat

PO: See if he wants to stay in a luxury room in a hotel that happens to be on the mountain: the dream of an entrepreneur in hospitality

PO: Take the learning from this situation to solve another problem: the academic's point of view

What this simple story demonstrates is that by looking at the same problem from different perspectives, we generate new options, some of which would probably never have come out of an approach of mono-disciplinary thinking. Muhammad and the mountain serve as a metaphor: in many situations we are confronted with Muhammads and mountains. In this speech we will explore some options to bring two parties together and initiate constructive dialogue between them. 
Now, let's go back to the world of today and tomorrow. In the 1950's, the legendary information theorist John von Neumann was paraphrased by mathematician Stanislaw Lem as saying "The ever-accelerating progress of technology gives the appearance of approaching some essential singularity in the history of the race beyond which human affairs, as we know them, could not continue." Vernor Vinge originally coined the term "Singularity" in observing that, just as our model of physics breaks down when we try to model the singularity at the center of a black hole, our model of the world breaks down when we try to model a future that contains entities smarter than human. Human intelligence is the foundation of human technology; all technology is ultimately the product of intelligence. If technology can turn around and enhance intelligence, this closes the loop, creating a positive feedback effect. Many scientists argue that the point of singularity could be reached within 30-40 years, which means before the year 2050!

Whether this scenario becomes reality or not, it is clear that the future can no longer be derived from extrapolating from the past. Paradigm shifts are occurring in many areas and, as complexity increases, our social and organizational structures are forced to change. Society is becoming increasingly complex, and understanding complex adaptive systems is critical to addressing key environmental, technological, biological, economic, and political challenges.

Therefore, to address contemporary and future issues and opportunities, we have to look for solutions in the 'hyperspace' formed by the combination of multi-disciplinary areas of expertise and creativity. The quantity and quality of knowledge in almost all fields of human understanding have grown impressively in the past decades. Correspondingly, in almost all fields knowledge centers, top institutes, expert networks and so on, have been set up or emerged from existing organizations and communities. However, the number of 'meta-structures', hypertext-like organizations, constructed over the traditional boundaries of disciplines, is still very small. This is partly due to the natural tendency of individuals and organizations to focus on their own, traditional areas of expertise and interest. In addition, language and cultural barriers make it difficult to successfully create new combinations, foster serendipity and explore the interdisciplinary cognitive space. In order to achieve break-through thinking and develop fundamentally new solutions, we have to bring ber of reasons, we will focus on Service Innovation. First of all, service 
industries are today the major contributors to the economy. Secondly, innovation in the service industry is still less well understood when compared to that in the product industry. Thirdly, services are always delivered in a compound context. For example, if there is no client, there is no way to produce the service: co-creation is by default an essential aspect of service production and delivery! Finally, as we will discuss later in this speech, technological development is a key driver of innovation in the service industries. These last two reasons make models for service innovation even more complicated and, I believe, implies that opensystem approaches are necessary.

\section{Creation and Mobilization of Intellectual Capital}

We live in an era with new drivers of value. The differences in managing knowledge, creativity and social networks explain why new companies are being established and others are going out of business, both at unprecedented rates. To date, it has been very difficult to develop quantitative measures that relate the intellectual assets of an organization to its economic value. In any case, these measures cannot (yet) be used in the way people use financial accounting metrics.

The importance of understanding an organization's intellectual capital is at least two-fold: Firstly, it could be used for analysis of the organization's performance, e.g. by business analysts. And secondly, Intellectual Capital directly relates to business strategy development.

Intellectual Capital is usually divided into Customer Capital, Human Capital and Structural Capital [Edvinsson \& Sullivan (1996)]. The importance of IC becomes clearer if we look at one extreme example, the value of the Internet retailer Amazon.com: The business of Amazon is not selling books (or being a virtual warehouse) - it is Customer Relations. The (market) value of Amazon is based entirely on its intellectual capital, the Customer Capital in particular. By selling books and other goods, Amazon has built an impressive customer base and the general opinion is that in some way or another this knowledge can be used to generate value and to create (financial) revenues. It is often extremely difficult to work out the detailed revenue-model as part of a business case for this type of activity, since (financial) input and output are separated from each other by a 'black box' which contains variables like: Capabilities to transform one form of capital into the other (Customer, Human, Structural, Financial), the organization's governance model, core competencies (modern organi- 
zations are more and more based on their competence-market-knowledge combination). Furthermore, for the realization of the potential revenues, often other entities in the organization need to be involved, which might lead to problems in materializing the business case if it doesn't take into account cross-boundary value creation. Therefore, we will need to replace conventional business cases, focusing on the growth of financial capital, by a sort of generalized hybrid cases in which there is input and output of both financial and intellectual capital.

Whereas financial capital may be scarce, intellectual capital is potentially limitless. By definition, this includes the organization's intellectual property - its legally protectable and exploitable intangible assets. However, intellectual capital is much more than just intellectual property. It is a compilation of the individual, group and corporate knowledge brought to the table in solving complex business problems. Intellectual capital represents the resources that produce imagination, inventiveness, and competitiveness, through the generation and dissemination of thoughts, ideas and fresh approaches. It is the sum and synergy of knowledge, relationships, processes, discoveries, innovations, market presence and community influence. As we will argue in this speech, when combined with the intellectual capital 'outside' the own organization this can lead to an unprecedented growth in the value-creating capabilities, and hence to the creation of new intellectual capital.

Intellectual capital implies more than just pure intellect. It also entails a degree of intellectual action. In this sense, intellectual capital is not a static, intangible asset per se, but it can only really be deemed a "capital" asset if it supports the strategic direction of the organization. Only then, we can speak of strategic value.

According to Roberts, Intellectual Capital is about letting the knowledge that is embedded in organizations do the work and create value [Roberts (1999)]. For the sake of our discussion, we propose the following practical definition for knowledge

Knowledge is the combination of three components: information, insights and imagination, that is being used to make a decision or to select an action by which a situation is changed into a more valuable situation. 
Knowledge exists within a certain context. In the following, we will refer to the context as the initial-situation, the transition process and the (desired) end-situation. The context also includes the actors, i.e. person(s), systems, organizations that are involved in the decisions and/ or actions that lead from the initial to the end situation.

The point is that we have far more knowledge and ideas that that we can express without the right context. Sometimes, knowledge cannot be expressed at all and it only manifests itself in the actions we perform or the decisions we make. For this, Polyani introduced the term 'Tacit Knowledge' [Polyani (1966)].

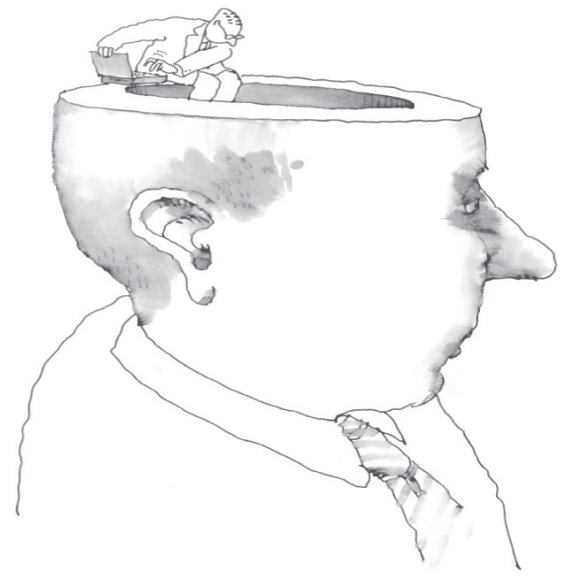

Figure 1. We know more than we can tell!

How often do people or organizations ask themselves whether they make optimal use of their knowledge? Are we motivated to ask questions like: What knowledge do I have? What could I do with it? Where can I get the knowledge that I need but don't possess? In particular, entrepreneurial people ask themselves these questions, consciously and unconsciously. I have done some research on this topic, and for this I have asked only one, simple and admittedly not very scientific, question: "Could you give an estimate of the percentage of your knowledge (insight, information, ideas) that you use in your daily activities?" The question has been answered by more than 930 people, all based in the Netherlands. The results of this survey are displayed in figure 2. 


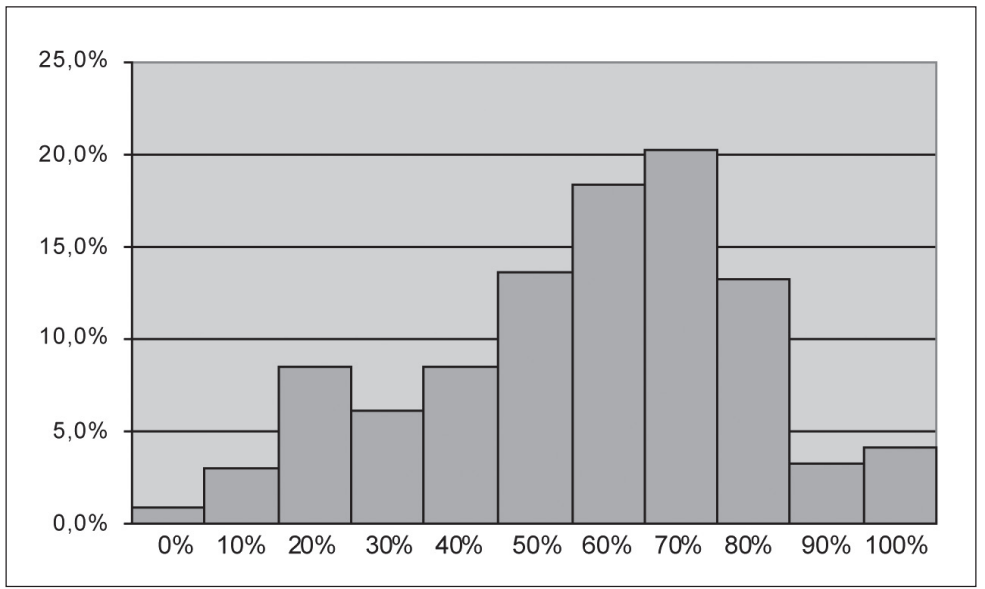

Figure 2. What percentage of your knowledge do you apply in your daily activities? ( $N=930)$ [Iske (2004)]

Now, I want to address the question of how to 'measure' the value of knowledge. From the arguments above, it becomes clear that the value of knowledge is not an intrinsic property, like the mass of a body. We define the Potential Value of a combination of knowledge components as the value that this combination could generate in all realizable contexts.

The added value can only be obtained if the components can be combined with other components so that knowledge is formed that actually can be used in the context. For discussion purposes, we propose a formula (see exhibit 1) that captures the essential process steps that lead to knowledge-based value creation [Iske and Boekhoff (2001)].

$$
\begin{aligned}
& \mathrm{V}_{P}(\mathrm{~K}(\Omega))= \\
& \sum_{\Gamma}\{\pi(\mathrm{K}(\Omega), \Gamma) \rho(\mathrm{K}(\Omega), \Gamma) \alpha(\mathrm{K}(\Omega), \Gamma) \mathrm{V}(\mathrm{K}, \Gamma)+\Lambda(\mathrm{K}(\Omega), \Gamma)\}
\end{aligned}
$$

Exhibit 1: Steps involved in knowledge-based value creation

In words, this formula reads:

The total potential value $V_{P}$ of the knowledge $\mathrm{K}$ that is embedded in environment $\Omega$, equals the sum over all contexts $\Gamma$ of the probability $\pi$ 
that this knowledge is associated with the context $\Gamma$, multiplied by the connectivity $\rho$ that indicates how easy it is to transport the knowledge from the environment $\Omega$ to the context $\Gamma$, multiplied by the absorption coefficient $\alpha$ that indicates how easy it is to apply the knowledge in the context $\Gamma$, multiplied by the added value $V$ that is achieved within the context $\Gamma$. Furthermore, additional value is obtained by learning, indicated by the term $\Lambda$.

The total potential value of all knowledge $\mathrm{K}$ in the organization then equals:

$$
\mathrm{V}_{P}(\mathrm{~K})=\sum_{\Omega} \mathrm{V}_{P}(\mathrm{~K}(\Omega))
$$

Exhibit 2: Potential value of knowledge assets in an organization

Many organizations are aware of the importance of managing their knowledge assets and various approaches for knowledge management have developed. However, most of the approaches, tools and interventions focus on knowledge sharing, which we indicated by connectivity $\rho$, and the application, or absorption $\alpha$. What I see to a much lesser degree, is an awareness of and effort in creating new areas of application of existing intellectual assets. It is about this simple question: What could I do, what could we do or what could you do with the knowledge that we have? An interesting example of the outcome of this question is provided by the Dutch mail service company TPG (now TNT), that has developed the program 'Move the World'. In collaboration with the World Food Programme, TNT is mobilizing knowledge and networks in the area of logistics to make a difference in the distribution of food for people who live in hunger (see: http://www.movingtheworld.org/).

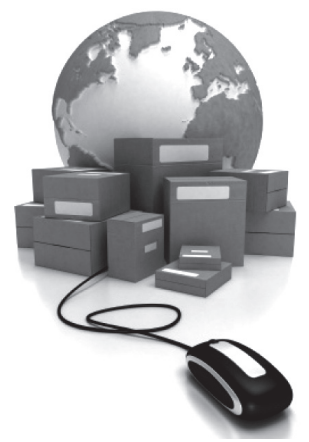

Figure 3. How knowledge in logistics can be used to create society value. 
By doing so, a lot value is created. In the first place value for society, starting with the people, especially children, who receive the food. And a society with healthy people, who are not hungry, is more stable and can focus on education, economic opportunities and so on. On the other hand, the people working with TNT are very much engaged in Move the World. It enhances the employee satisfaction and company pride of the staff, which adds to the human capital of TNT. So, this is an interesting example of how one component of intellectual capital (structural capital) is used and transformed into another form (human capital), just by asking that simple question on how existing intellectual assets could be leveraged in a new context.

I will now discuss an example of a dialogue that should be further developed and where the creation and combination of knowledge will boost value creation. It is well-known that the role of the creative sector in the economy is becoming increasingly important. It is important to note that the creative sector consists of much more than artistic activities. Companies, active in areas such design, gaming, advertisement, fashion, architecture and media (see figure 4), all have in common that intellectual capital is the most important resource they require for value creation.

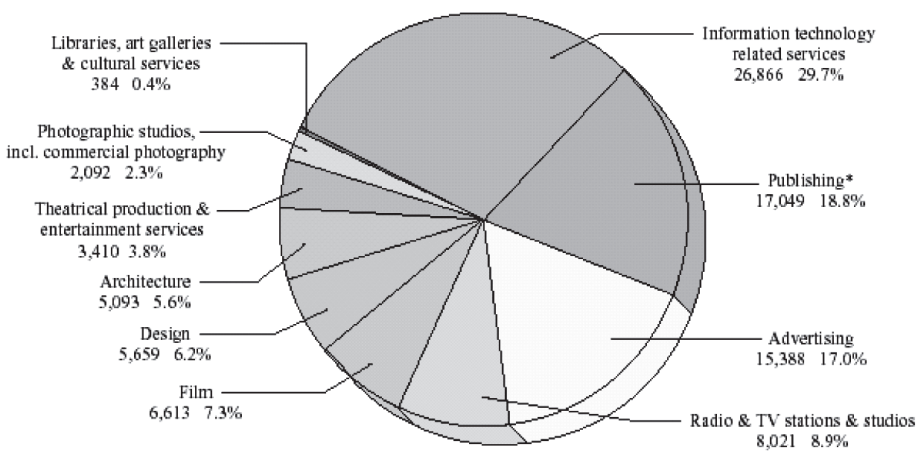

Figure 4: Sectors in Creative Industry. Hong Kong's Creative Industry Employment as of March 2002 (\% Share)

Richard Florida has given in his book 'The Rise of the Creative Class', a compelling story about the importance of the creative class and the specific needs they have. On the other hand, in his book 'The flight of the creative class' Florida argues like many others that without an 
inspiring and productive environment, it is difficult to attract and retain creative workers and entrepreneurs. One of the most important issues is the financing of creative ventures. Traditional models for debt or equity financing are predominantly based on existing and projected cash streams, as well as assets like buildings, production equipment, financial reserves and so on. But starting creative entrepreneurs have nothing of this all. When they start, intellectual capital is the most important feedstock for their business. And here we have the core of the problem: apart from formalized intellectual properties, such as patents, financial institutions don't know how to deal with intellectual capital as a source of value creation. It simply doesn't fit in their models. The conclusion is that there is currently no initial framework for dialogue between the creative and financial sectors, hence there is no environment for joint value creation. It is, in fact, very similar to the problem of Muhammed not coming to the Mountain. So how can we solve this?

PO-1: Extend the current financial models by adding components that describe the creation and transformation of intellectual capital. People like Leif Edvinsson, Baruch Lev and Thomas Stewart have started a movement to make intellectual capital more explicit and measurable. We have already seen that one of the biggest challenges in the valuation of intellectual capital is that the value is not an intrinsic property, but a potential for which realization depends on internal factors, such as entrepreneurial qualities, and external factors, including coincidence! The wide gap that currently exists between the existing financial frameworks and the world of the creative sector can be reduced by gaining more insight in the relation between financial and intellectual value drivers.

PO-2: Add an intermediary party that can connect to both worlds, speaks both languages and can transfer and translate messages from one side to the other. By doing so, mutual understanding will grow and a dialogue will develop.

PO-2a: The facilitating intermediary is a professional party with expertise and networks in the creative industries on the one hand and financial expertise and access to banks and equity providers on the other hand. As an example, the concept of a 'Creative Industry SOFA' (they were not allowed to use the word Bank) has been developed by a former CEO of an advertisement company, to 'Connect Content and Concept to Care and Capital'. Various products and services are being developed 
by the SOFA, such as self-assessment tools for creative entrepreneurs, a knowledge base for parties to better understand the principles of the creative industry, networks of people to assess the potential of a creative enterprise, and (hybrid) funding opportunities.

PO-2b: Ask the public! Who is the expert? Surowiecki describes in his book 'The Wisdom of Crowds' how a large groups of people can engage in a 'knowledge market'. The analyzing and predicting capabilities of such crowds can be impressive, which is caused by a constructive combination of experiences and perspectives. In fact, a huge configuration space can emerge, when knowledge interactions and transactions are supported in the right way. Also in Sunstein's book, 'Infotopia: How Many Minds Produce Knowledge', transaction-based knowledge sharing, discovery and application are explored, based on methods for aggregating information. It contains discussions of prediction markets, open-source software, and wikis. For our case, the crowd can be asked to form an opinion that supports the decision process of the investor. But members of the crowd can then also decide to invest themselves, possibly in the form of small shares. This funding mechanism is called crowd funding and is an interesting form of creating value out of combined intellectual and financial assets by democratizing the investment process. Crowd funding works best is there is engagement, which means that relational and social capital is being transformed into financial and innovation capital. If the receiving party is a social enterprise, the output will be in the form of social capital.

The example of the creative industry is not unique: The same problems occur in the valorization of Research \& Development, the inclusion of sustainability aspects in business plans, the financial support of charity, and other economic activities in which non-tangible value plays a role. In all cases, the approach of crowd funding entails an intellectual (and often emotional) engagement in the subject matter. Many initiatives have been started to better understand this phenomenon. It promises to offer significant new funding opportunities, that for example for academic research could be indicated as the 'fourth income stream', in addition to direct and indirect governmental funding and contract research.

The exploration and discovery of new areas of application is a creative activity. It requires the ability to connect to new environments, to make new combinations. Some courage is also necessary to challenge current practices and think about solutions that come from outside the system. This is the essence of PO. Thus, creativity will be key for creating unique 
perspectives, based on the combination and application of existing and newly-generated knowledge. And this too, requires change in the 'structure' and culture of organizations. Sometimes people ask whether creativity can be measured, and the surprising answer is: 'Yes it can!'.

In 1968, George Land applied a test, used by NASA to assess creativity, to children of age $5,10,15$ and to adults of various ages. It turns out that creativity goes down rapidly with age and it reaches a minimum at the age of 44, which is called the state of 'Terminal Seriousness'. The creativity increases after retirement, which is an interesting fact given the current discussions on increasing the age of retirement because of the increase in life expectancy.

The results of this research are shown in Figure 5 [Land and Jarman (1993)].

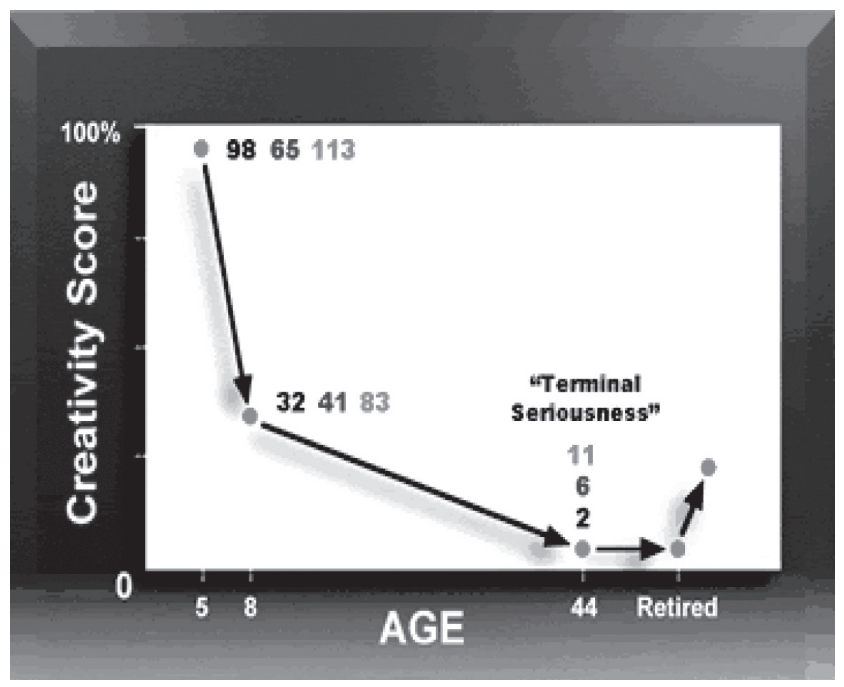

Figure 5. The development of the creativity index, measured as function of age

There is another interesting way to arrive at the same conclusions -the idea is that creativity is the ability to create new solutions to existing or new problems. In fact, we talk about generating new patterns. There are two ways to increase the number of patterns. The first way is by asking questions. By so doing, you 'grow' an openness for new knowledge and new patterns. The other way is based on making new combinations, which also generates new patterns. Humor is a good example of a process 
in which new combinations are being produced. At the 'punch line' of a joke, things are connected in a surprising, and sometimes illogical way, producing a new combination. Now take the number of questions one asks during a day and multiply this with the number of times somebody laughs. Then we get the 'creativity index'.

This approach may seem a bit frivolous, but I believe that it has inspired and guided me in many aspects of my thinking. In fact, I see it as an important task for me to design and support the creation of environments where people want and dare to ask questions and are open for new combinations, for a discovery dialogue with people from different disciplines. This is the way to increase one's configuration space, to boost creativity and create opportunities for new knowledge-based value creation!

\section{Combinatoric Innovation}

Innovation is important to deal with the challenges and opportunities that we are facing. But what is innovation? We propose the following working definition:

Innovation is the process in which is value created by the application of knowledge assets where this didn't happen before.

From this we conclude that just doing something new, does not automatically lead to innovation: value has to be created. Furthermore, it is not always necessary to create new knowledge, as long as it is used in a new context.

There are different forms of innovation. It can range from rather incremental, dealing with improving or increasing the current business, up to radical transformation of the business, as indicated in figure 6 . 


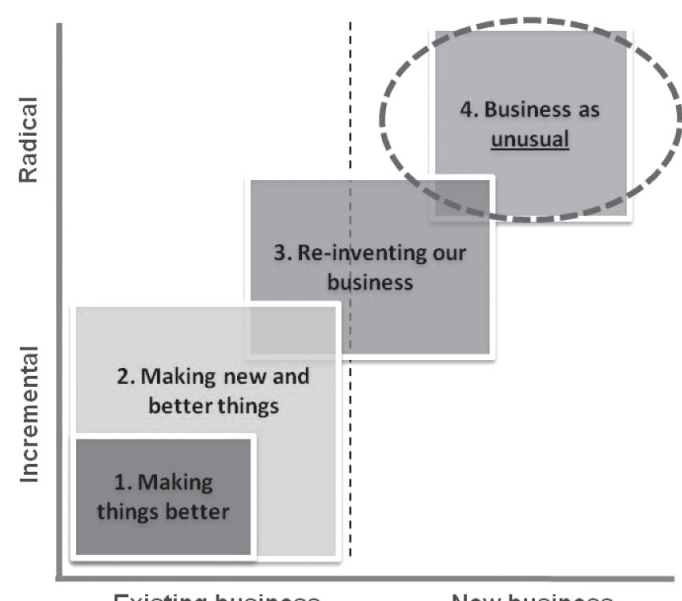

Existing business

New business

Figure 6: Various forms of innovation

The first two types of innovation relate to the existing business and focus on improving quality and business processes (type 1) and on increasing revenues (type 2). Innovations of type 3 deal with business transformations that give the company access to other revenue streams, e.g. by repositioning in the value chain. Finally, type 4 innovations are targeting new revenue streams, hence the label 'business as unusual'. Especially, but not exclusively, in more transformative innovations, we often see the impact of complexity and paradigm shifts. The drivers for change are simply not on the radar screen of the managers of the established organizations. They suffer from the not-invented-here syndrome or they simply fail to understand the potential impact of new developments on their own business. And before they can act, the world has changed, and is full with paradoxes which confuse them. In his book 'The Innovator's Dilemma', Clayton Christensen gives a good analysis and numerous of examples of disruptive innovations that had a profound impact on established companies or even complete industries.

A paradox is a true statement or group of statements that leads to a contradiction or a situation which defies intuition. Examples of paradoxes that confuse managers include: 'expensive is cheap' (think of valuable content that is now available for free), weak has power (for example the change in power balance between patients and the health professionals), 'poor people are valuable customers' (the 'Long Tail', described 
in Prahalad's 'The Fortune at the Bottom of the Pyramid') and 'best practices are worst practices' (for example the successful financial products that are at the basis of the current economic crisis). In literature a paradox can be any contradictory or obviously untrue statement, which resolves itself upon later inspection. And the best way to do this inspection is by looking from outside-in, thereby allowing new perspectives to be added to the intuition and established patterns that dominate the decisions within the organization.

To better understand the nature of paradigm shifts, or breakthrough innovations, it is interesting to make a comparison with phase transitions in physics, which are defined as the transformation of a thermodynamic system from one phase or state of matter to another. At a phase transition of a given medium certain properties of the medium change, often discontinuously, as a result of some external condition, such as lowering or increasing the temperature. The combination of the external conditions at which the transformation occurs, is termed the phase transition point.

Phase transitions are common occurrences observed in nature and many engineering techniques exploit certain types of phase transition. In all cases, a system can be described in terms of a number of parameters and the state of the system depends often on ratios of these parameters. Take for example the melting process: atoms or molecules in a solid are fixed to their positions due to the binding forces. To destroy the order, the thermal (kinetic) energy of the particles must exceed the binding energy, so that they can 'escape' from their positions and the system becomes a fluid. The thermal energy increases with the temperature, so there is a critical temperature above which the solid will melt. So, the state of the system is determined by the ratio of two energies thermal versus the binding energy. And this ratio changes by changing one or more extrinsic variables, such as the temperature. Other phase transitions in physics include superfluidity, where the viscosity of a system abruptly drops to zero at a critical temperature and superconductivity, where resistance of a material abruptly drops to zero below a certain critical temperature. Both superfluidity and superconductivity are examples of phase transitions than can only be understood by using the framework of quantum mechanics. For a good overview of the area of statistical physics dealing with phase transitions, we refer to Stanley's standard work 'Introduction to Phase Transitions and Critical Phenomena'. 
The general observation at phase transitions is that system properties change on a macroscopic scale. Following the analogy, for breakthrough innovation this would translate in a significant change in behavior of the market or (parts of) the society. And if it becomes clear that things might or will change, it is usually very difficult, if not impossible, to predict when the new order will be established. Even for relatively simple systems like the ones we encounter in physics, it is very difficult to determine the phase transition point exactly. It is therefore easy to accept that for very complex systems, with very complicated constituents (such as human beings!), it is impossible to make precise predictions. Malcolm Gladwell's book 'The Tipping Point' explores more or less the same phenomenon by addressing the question of how little things can make a big difference.

So, we may conclude that breakthrough, disruptive and system innovation can be compared to phase transitions: due to changes of certain external variables, system properties can change disruptively. Clayton Christensen describes in his famous book 'The Innovator's Dilemma' how disruptive technologies upset well-established and respected companies. One of the main conclusions is that people tend to ignore weak signals for too long simply because they don't have a feeling for the impact of the changes when the effects become of macroscopic size. And the root cause is often that the changes are driven from outside the traditional system. As stated, this is also the case at phase transitions in thermodynamic systems, which were driven by extrinsic variables as well. This is yet another reason for bringing in external perspectives in the strategy and innovation processes.

Looking deeper into this issue, one can observe that system changes usually are driven by a fundamental change in a characterizing ratio of system parameters. Take for example on-line auction sites like eBay. If one wants to sell or buy a product or service, this only makes sense if the transaction cost is (considerably) lower than the transaction value. In the past, one had to make use of advertisements to sell to an unknown transaction partner. This resulted in a minimum transaction value, which in many cases prevented the development of a considerable market. Services like eBay-type enable the facilitation of transactions of only a few US\$ or Euros. The relevant ratio in this case is Transaction cost divided by Transaction value: $\eta=C_{T} / V_{T}$. For this ratio to become smaller than 1 , a technical development (internet-based auction) had to take place. The result is a whole new services business model. 
The mobile music industry is another example of a disruptive innovation caused by a ratio that changed fundamentally. The driver of change is here the 'weight of $1 \mathrm{~GB}$ of memory'. 1GB is the order of magnitude of information that corresponds to a CD. People are willing to carry device of the order of $1 \mathrm{~kg}$, otherwise it is not considered portable. So, miniaturization of storage media (apart from mechanical parts) had to take place, before the mobile audio and video industry could take off. Likewise the development of the Tourist industry really 'took off' as a result of technical innovation, including aviation. Before commercial air travel, there was very limited market opportunity for tourism to exotic destinations, simply because the travel time was large compared to or even exceeding the available holidays. So the critical ratio here is travel time divided by length of holidays and this ratio needs to sufficiently small to make the trip worthwhile (or even possible) - so that we can calculate the necessary 'critical speed'. If we assume that the travel time needs to be one order of magnitude smaller than the length of the holiday, this implies a maximum travel time in the order of one day. For intercontinental trips, which have a distance in the order of $10.000 \mathrm{~km}$, this implies a speed of at least $500 \mathrm{~km} / \mathrm{hr}$. Such speed only became possible with the development of modern aircraft. An interesting observation is that one could have predicted a whole new tourist industry before it actually happened!

It is also interesting to note that though the drivers of change in the examples mentioned above were technical innovations, in both cases it resulted in radical service innovations.

We can conclude that, with some fantasy, it becomes possible to predict disruptive changes before they actually happen and to get a better feeling for the timing of these events. This thinking is closely related to scenario planning, which also is also an outside-in process, where trends and events in the external world are combined with the properties of the organization. This means that in modern society it becomes increasingly important to be connected and to share ideas, experiences, insights and information. However, due to the complexity of the world, there is no guarantee that results will come immediately, if at all. Side effects, longterm consequences, weak signals may still be ignored or not understood. This is where serendipity comes into the picture. Serendipity is defined as the talent to make valuable discoveries by coincidence, typically when looking for something else. The first noted use of this word was by 
Horace Walpole (1717-92). In a letter to Mann he said he derived it from the Persian fairy tale "The Three Princes of Serendip," whose heroes "were always making discoveries, by accidents and sagacity, of things they were not in quest of." The Dutch eye surgeon Pek van Andel gave the following interpretation of the word: "Serendipity is looking for a needle in a hay stack and ending up with the beautiful daughter of the farmer." I believe that serendipity can be developed as a competence. It is strongly related to creativity and to entrepreneurship. Entrepreneurship is an attitude, for which we refer to a definition that is being used by the Commission of the European Communities in the Green Paper 'Entrepreneurship in Europe' (2003):

"Entrepreneurship is the exploitation of creative and/or innovative ideas"

"Entrepreneurship is first and foremost a mindset. It covers an individual's motivation and capacity, independently or within an organization, to identify an opportunity and to pursue it in order to produce new value or economic success." Some attributes that come with this description include: Passion, Risk-taking, Outward-looking, Flexibility, Stamina, Focus, Result-oriented, Independence, Creativity, Rule-breaking, Networking, Intelligence, Pragmatic. So, new talents and skills need to be developed. In particular, the abilities to utilize knowledge in different areas, to create a multi-stakeholder, multi-disciplinary perspective and to innovate on a cross-sector basis will create new ways to create value. It requires entrepreneurship with a focus on ideas that come from elsewhere. It has been stated, amongst others by Prahalad and Krishnan in their book 'The New Age of Innovation", that in the coming decades more innovation can be expected from new, collaborative business models compared to innovation originating from (mono-disciplinary) product development. When well-organised, so-called open innovation or co-creation, can deliver great opportunities for fast and better development of new products, services as well as support public and social entrepreneurship. "Open innovation is the use of purposive inflows and outflows of knowledge to accelerate internal innovation, and expand the markets for external use of innovation, respectively. This paradigm assumes that firms can and should use external ideas as well as internal ideas, and internal and external paths to market, as they look to advance their technology", according to Henry Chesbrough in his book "Open Innovation, Researching a New Paradigm". Open Innovation focuses on bringing into the firm knowledge for solving problems that the organization is struggling with. Co-creation aims 
primarily to bring in the customer's perspective, so that better understanding of current and future needs can develop. A nice example of co-creation is the LEGO DESIGNbyME, where consumers (usually LEGO adepts) propose new models, which can be reviewed by other participants. By facilitating this on-line community, LEGO builds an understanding of potential products that serve customer needs and expectations. Crowd Sourcing is widely applied nowadays to get access to both individual's needs as well as to solutions. Thus, it can be applied for both open innovation as well as co-creation. The first well-known example of crowd sourcing is InnoCentive. Pharmaceutical maker Eli Lilly funded InnoCentive's launch in 2001 as a way to connect with brainpower outside the company - people who could help develop drugs and bring them to market. From the outset InnoCentive threw open the doors to other firms eager to access the network's 'treasure trove' of ad hoc experts. Companies like Boeing, DuPont, and Procter \& Gamble now post their most ornery scientific problems on InnoCentive's Web site and anyone on InnoCentive's network can take a shot at cracking them. The companies - or seekers, in InnoCentive parlance - pay solvers anywhere from $\$ 10,000$ to $\$ 100,000$ per solution. (They also pay InnoCentive a fee to participate.)

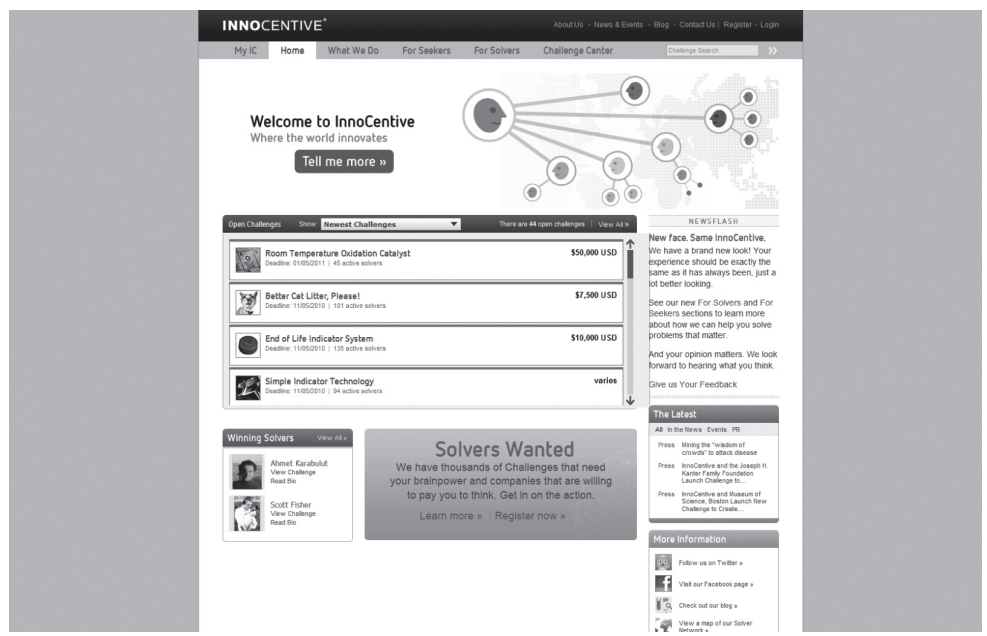

Figure 7. Home Page of Innocentive's website 
According to InnoCentive, more than 30 percent of the problems posted on the site have been cracked, "which is 30 percent more than would have been solved using a traditional, in-house approach." One of the solvers is a physicist. For quite some time, he has logged onto the network's Web site a few times a week to look at new problems, called challenges. InnoCentive is nowadays focusing on many problem areas, but in the beginning most of these could be categorized as either chemistry or biology problems, for which he had no formal training. "I saw that a lot of the chemistry challenges could be solved using electromechanical processes I was familiar with from particle physics," he says. "If I don't know what to do after 30 minutes of brainstorming, I give up." So, bringing together knowledge to solve a problem can yield great results. But not always the problem or opportunity is already clear from the beginning.

Therefore, we introduce the concept of Combinatoric Innovation:

Combinatoric Innovation is the process of discovering new ways of value creation by combining and applying previously disconnected intellectual capital from two or more sources.

The basic mechanism behind Combinatoric Innovation is the extension of configuration spaces, which allows for the identification, explicitation and understanding of new categories of problems and solutions. Combinatoric Innovation could be seen as a new aspect of Open Innnovation in which there is a very important role for serendipity, for discovery by trial and error. It focuses on a specific way to explore the possibilities and create new opportunities for 'traditional' forms of Open Innovation. Because multiple mental spaces are involved, a considerable amount of PO can be expected. It is also a mechanism that can be used to determine or develop 'Blue Oceans', a concept that was introduced by Kim and Maurborgne. Blue Oceans are business models based on complete new sets of value propositions, making competition (for a while) irrelevant.

In Open Innovation, one usually starts with the problem and then looks for combinations of knowledge assets to tackle the problem. In Combinatoric Innovation, it works the other way round: the combination of intellectual capital is facilitated, followed by the question: What can we do with this? Or: Where could this add value? In this way, Combinatoric Innovation is more a methodology comparable to Systematic Inventive Thinking. In SIT one applies a number of principles to construct out of existing systems, products or services, a half-fabricate with new, combined, changed or 
re-arranged features. Then the question is asked: what kind of new applications could be related to this intermediary result? From this point, converging takes place again and ways to achieve the application are being explored, resulting in engineering of the solution. It turns out that more than $70 \%$ of all innovations can be reconstructed following this methodology. Combinatoric Innovation leads to surprises. Generally, one starts with a wide area of interest, a theme - however, exactly what problem or opportunity will be addressed is a matter of discovery. It is like the combination of DNA which gives us children with recognizable elements, but with also with a largely unpredictable individual potential. So, it is the combination of DNA material that makes us unique human beings, whereas the building blocks are quite universal for all of us.

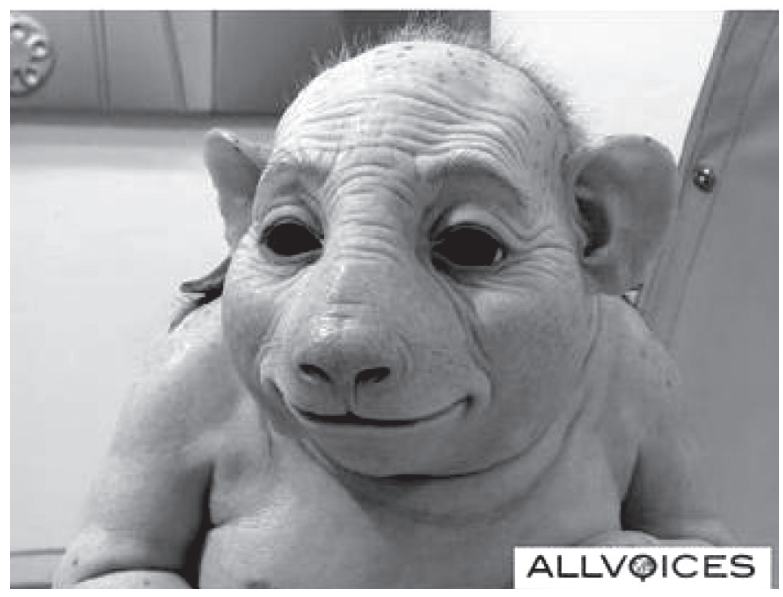

Figure 8: Combinatoric Innovation: Life is full of surprises!

Combinatoric Innovation is a group process and therefore, it is interesting to discuss the possible connection with communities, especially those focusing on intellectual capital related activities. Communities are as old as man-kind, but in recent times the word Community has acquired additional meaning in the context of new business models on one hand and developments in the ICT environment (in particular the Internet) on the other hand. It is generally perceived that communities are the key constructs for business innovation and coherence in the New Economy and the challenge is to support the creation and leverage of meaningful communities that add value to their members and their environment. 
Typically, one distinguishes four kinds of communities in the organisational/ICT context:

1. Informal Networks: Networks of people who know each other and communicate with each other outside the context of directly shared (business-oriented) goals and/or interests.

2. Communities of Interest: Good examples are discussion groups and chat-boxes, which we find on the Internet (or an intranet). Here people are joined together by a common interest.

3. Communities of Practice: This is a set of practitioners and/or professionals who have similar tasks or challenges. The driving force in the community is the exchange of experiences and ideas allowing the members to do their job better and more efficiently.

4. Communities of Purpose: Here goals and targets can be set at which professionals collectively can aim. Collaboration between the members is essential to achieve the desired results. The group is collectively responsible for generation of business benefits. A project team is a good example of a Community of Purpose.

'Leveraging Communities of Practice for Strategic Advantage' by Hubert Saint-Onge and Debra Wallace, is one of the many books describing the challenges and opportunities when working with Communities of Practice.

Combinatoric Innovation takes as starting point the building blocks of intellectual capital present in a certain, diverse, group. From this, an explorative journey starts to find out if, where and how value could be created. I would like to use the phrase Community of Serendiptiy to describe such a group, referring to the primary 'business process' that takes place here. The most important activities in such a group are questioning and combining. As a result, the creativity index can be comparable of that of a 4-year old child! It might be clear that such a Community of Serendipity differs from Communities of Practice, which bring together practitioners with comparable backgrounds and tasks.

\section{Network Social Innovation at Maastricht University}

It is generally accepted that in addition to product and service innovation, there is a need for so-called Social Innovation. According to the Wikipedia, Social Innovation can be described as: "Social innovation refers to new strategies, concepts, ideas and organizations that meet social needs of all kinds - from working conditions and education to community development and health - and that extend and strengthen civil society." The 
Network Social Innovation (NSI) at the Maastricht University focuses on social and organizational innovations to improve the development and use of talent and know-how and ultimately firm performance. It is clear that Social and Combinatoric Innovation as a strategies for creation and mobilization of Intellectual Capital have a lot in common.

Furthermore, multiple perspectives also play a role in the approach of the Network Social Innovation, since NSI believes that progress in the understanding and application of social innovation can only be achieved if science, business and social organizations join forces. By focusing research on issues that firms and other organizations face in real life, and by studying these issues with a scientific approach, we will be able to gather knowledge about social innovation processes that are of direct importance to the economy.

\section{Service Science Factory at Maastricht University}

A good example of this way of organizing serendipity and managing the early stage of Open Innovation is the recently started Service Science Factory at the University of Maastricht, which is an innovative place where students, researchers and professionals work in a pressure-cooker environment to invent new services or improving existing ones.

The Service Science Factory offers companies, governmental entities and different organizations the possibility to present their problem areas to dedicated project teams, which after eight or sixteen weeks give them a concept describing a complete service or its prototype. Basically, the raison d'être of the Service Science Factory is the fact that the dispersed intellectual capital of universities and their network partners is hardly accessible, especially in cases where multidisciplinary contributions are required to make real progress.

So, both the Network Social Innovation and the Service Science Factory are strongly related to Combinatoric Innovation: The NSI helps to understand the conditions for Combinatoric Innovation, whereas the Service Science Factory is a 'laboratory' for testing the concept in the practice. 


\section{Environments for Combinatoric Innovation}

Combinatoric Innovation is about environments where people connect and combine. Where new ways of value creation can be discovered and developed. But what is an environment? And what are the key properties of environments for Combinatoric Innovation?

According to the American Heritage $\odot$ Science Dictionary, an environment can be defined as follows:

\section{environment}

All of the biotic and abiotic factors that act on an organism, population, or ecological community and influence its survival and development. Biotic factors include the organisms themselves, their food, and their interactions. Abiotic factors include such items as sunlight, soil, air, water, climate, and pollution. Organisms respond to changes in their environment by evolutionary adaptations in form and behavior.

In our context, we are looking for interactions with the environment that influence human and organizational behavior. These are found in four 'spaces':

A. The social space, describing informal relationships, cultural aspects, networks, codes of conduct and so on;

B. The process space, which contains the way the activities have been organized and formal relationships are defined;

C. The virtual space, consisting of ICT-based systems, such as communication tools, social networks, workflow tools, transaction systems and mobile infrastructures;

D. The physical space, which directly interacts with our five senses: sight, smell, sound, taste and touch.

When we are looking for value-adding environments, we might reformulate this as:

A value-adding environment is an interplay between the process, social, virtual and physical spaces, supporting people in their well-being, fulfilling their tasks and/or reaching their ambitions. 
In particular, we are looking for properties of environments that support Combinatoric Innovation.

\section{A. Social space for Combinatoric Innovation}

The well-known author Charles Leadbeater made an interesting comparison between evolution and innovation [Leadbeater (2000)]. He identified nine drivers for evolution that can be mapped on corresponding properties of innovative environments. The most important driver for innovation is 'diversity'. In nature, diversity is used to generate new DNAcombinations that can more easily adapt to the surrounding environment. However many organizations, and society in general, consider diversity to be a problem, a liability instead of an asset. But successful organizations know that diversity is a driver for value creation! In this context, I am not talking only about gender diversity or about the positive impact of having people from different cultures. What I am talking about is a productive usage of different mental models, a dialogue between different worlds.

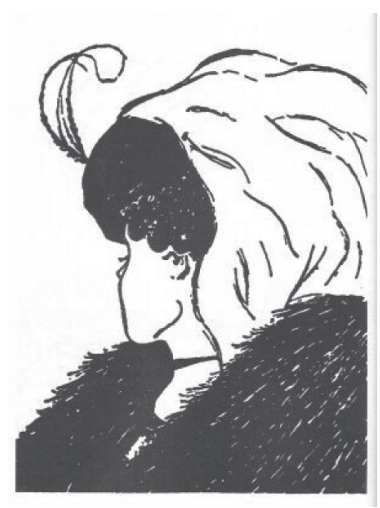

Figure 9. Different mental models produce different views.

As an example, look at the current economic crisis [Iske \& Saint-Onge (2009)]. Worldwide, financial and economic experts struggle to make sense of the credit crisis and the resulting economic recession and to find meaningful solutions. Everyone agrees that the situation contains unprecedented aspects, so that applying lessons from the past does not guarantee success. We will need a paradigm shift to sort this out. Indeed, as Einstein said: "We need new ways of thinking to solve problems caused by the old ways of thinking." It seems naive to believe that the 
answers to the current challenges can be found exclusively within traditional disciplines dealing with finance and economics. Let's face it: the conventional experts didn't predict the crisis to the full extent and for sure they didn't stop it from happening! Therefore, we need 'new combinations', in other words the involvement of other areas of expertise. For instance, the developers of operating systems like Microsoft Windows may bring an interesting frame of mind to this discussion. As many users have experienced, a complex system such as Windows tends to crash every now and then. However, to reduce the pain, "System Restore" has been developed, which enables the user to bring the system back to the state it was in before the occurrence of a problem. Maybe, this notion could apply to the financial system to ensure an early recovery from a serious problem. Lehmann Brothers bankrupt? Whoops! Let's use system restore and try it again! We could ask developers from the open source community to participate, since they know how to start from scratch instead of just patching and expanding systems and achieving this by combining the input from the crowd.

Think about the creativity and the paradigm shifts that can be produced when we bring different disciplines into collaborative thinking. Combining knowledge from many different perspectives will result in significant new and surprising insights and results. But ensuring that these conversations are productive and that all participants approach them with an open mind, needs to be managed with careful orchestration and facilitation. All this can be brought to bear to leverage the multiple perspectives that will give us creative new solutions to apparently untractable problems.

An other interesting aspect of an innovative climate put forward by Leadbeater, is indicated as 'Redundancy'. This is a tricky one, especially today, when almost every organization suffers from 'Corporate Anorexia Nervosa' or 'the unquestioned worshiping of the god of efficiency'. Waste is not acceptable and failures should be avoided at all cost. If they occur we try to hide them as much as possible. Current financial models stimulate risk avoidance and R\&D programs that deliver exactly what they promise are considered to be very successful. But real breakthroughs cannot be predicted, and paradigm shifts mark a situation in which the new situation is not just the continuation of the past, which is also the main theme of the famous book 'The Black Swan' by Nassim Nicholas Taleb. 
The important role that failure plays in the process of innovation merits a much more positive view: It is about trial and error, so failure should be an option! To promote this message, the Institute of Brilliant Failures has been set up. The Institute aims to bring about a shift in the way we view failure. Time and time again, history has demonstrated that our most valuable experiences are more likely to come as mistakes than as successes. The institute wants to be a tribute to all of those who had the courage to try something different. We learn from failures and our failures may be a source of inspiration for others. Much is wasted in a culture where failure is viewed as unacceptable and few are prepared to take the necessary risk. Let's share, is the message.

A good example is the well-known drug Viagra. The pharmaceutical company Pfizer wanted to develop a medicine for angina pectoris, chest pains and high blood pressure - a great intention indeed. Pfizer invested in and carried out clinical trials for six years. In that period a side-effect was discovered by half of the trial population, which was appreciated by the other half. Now, an average of nine Viagra pills are dispensed every second.

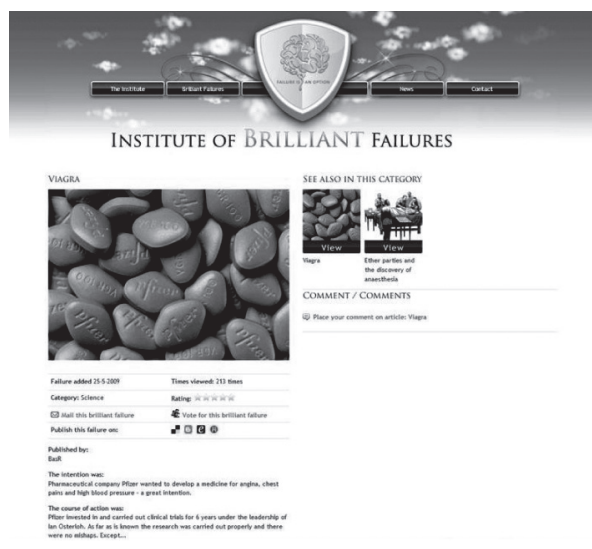

Figure 10. Screenshot from the website Institute of Brilliant Failures (www.brilliantfailures.com)

We will come back to the aspect of failure when discussing the process space of Combinatoric Innovation. 
Another aspect of an innovative climate is: 'Co-evolution', which means that organizations are active in an 'ecosystem' in which success can only be sustainable when there is mutual value creation and a continuous dialogue takes place. A good example of this situation is Apple and the community of application developers for iPod, iPad and iPhone. The success is further strengthened by the fact that many suppliers have created accessories, like cases, loudspeakers, car kits etc. which leads to customer lock-in. Here too, it becomes clear that the combination of different disciplines can lead to a very attractive new business model, allowing many parties to benefit from their own activities, but also from that of the others.

'Unlearning' is also a quite relevant aspect of an innovation-friendly climate. We are used to valuing the knowledge that has been developed in the past and which has contributed to the organization's success. However, there is a 'half-life' for the value of knowledge, which in many cases is becoming shorter and shorter at an ever increasing pace. In an environment that is supportive for Combinatorial Innovation, the partners accept that sometimes part of their knowledge is no longer stateof-the-art and that instead it is better replaced by that of the other. This requires respect, trust and should not be hindered by an ego or perceived authority based on hierarchy, age, reputation and so on.

The last Leadbeater criterion I would like to mention is 'Timing'. "Too early is also not in time", is what I say when I arrive somewhere too late. In fact, wrong timing is the most often-seen reason for failure in innovation. The best way to avoid unnecessary failure is to stay in constant dialogue with the relevant parties. For this, an open attitude is mandatory, being able to pick up early and weak signals, interpret them and act upon them! The openness also requires listening to non-usual suspects. The knowledge about our complex society is dispersed and finding it is quite often a process of discovery rather than search and find or buy, no matter what many consultancy firms want us to believe.

\section{B. Process space for Combinatoric Innovation}

There are quite a number of processes and process-related issues that play a role in developing capabilities for Combinatoric Innovation. Here too, it is important to appreciate the fact that in multi-party, multiperspective situations, a degree of complexity is added. It means that business navigation and emergent strategy will grow in importance at the expense of control and top-down strategy. 
What kind of processes are we talking about? First of all, it is about the group process, for which some the social interactions are part of the social space that we described before. Furthermore, I will say a little about some process aspects of Innovation that are characteristic for Combinatoric Innovation.

\section{The development and facilitation process of a Community of Serendipity}

First of all we could look at the dynamics of the Community of Serendipity that we introduced earlier in this speech. We will take a closer look on the process of community development. In physics and chemistry, one distinguishes between endothermic and exothermic processes. Processes in the first category require a continual input of energy otherwise the process stops. As an example, one could think of boiling water in a kettle. The boiling stops immediately when the heat is no longer put into the process. In contrast, an exothermic process is sustained by the energy that it generates itself, possibly after having received some energy for the start, the so-called activation energy. An example within this category is burning a piece of wood. Some heat has to be put in, but after that the reaction heat is (partly) used as activation energy for further combustion. In terms of community development, it means that we are looking to design and facilitate the group process in such a way, that an 'exothermic' situation arises, in which in the beginning some start-up energy needs to be inserted, but after a while the community becomes 'self-heated'. One should never forget that people only voluntarily share their knowledge. Therefore, the right conditions need to be created.

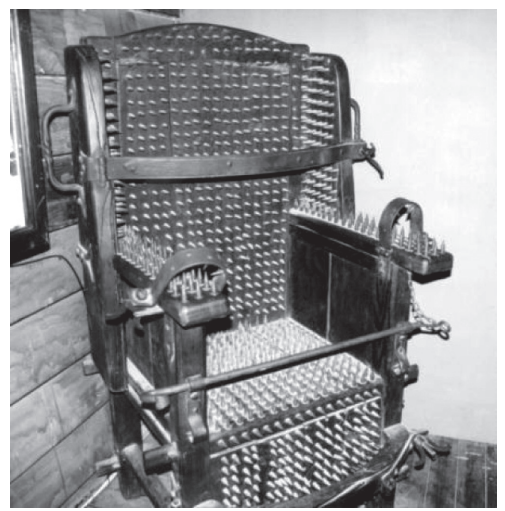

Figure 11: Sharing knowledge cannot be forced. 
There are some necessary, but not sufficient, conditions that are required for a successful, 'exothermic' community as can be found in Weggeman's book 'Kennismanagement' ('Knowledge Management') (1998):

1. Collective ambition: Though all members have their own background and responsibilities, they need to be able to relate to a certain theme or common area of interest where they want to join forces;

2. Facilitation: Especially in the beginning, the community can benefit from facilitators who feel a responsibility for the group performance and who have experience in leveraging the capabilities and ambitions of groups;

3. Respect and Trust: There cannot be a meaningful, open conversation if the members do not have respect and trust for each other, albeit that they have different backgrounds, experiences and opinions;

4. Meeting place: The group benefits from an inspiring and productive place to meet, which usually will be a combination of a physical and a virtual space, as I will describe hereafter.

Following Tuckman, a group is generally believed to go through the following stages while developing itself: Form, Storm, Norm and Perform, to which the stage of Adjourn could be added, indicating the finiteness of the process [Tuckman (1965)]. In our case we have to take into account specifically the fact that we are dealing with diverse people with overlapping interests and complementary intellectual capital relating to a (wide) theme.

We start with the Forming stage: The discovery of opportunities for joint value creation will be an experience of serendipity on the one hand, but it can benefit from facilitation efforts. In this stage, the dialogue has to develop, for which good practices are available. Forming happens when people first meet. The conversation is mostly exploratory, finding out about one another and shared interests. People here are typically quite excited about the newness and the potential for learning from new opportunities. Managing the 'form' stage is best done by introducing people to one another and ensuring the quiet ones are drawn in and not left out. Rituals may be used to introduce people and for ensuring their engagement in the dialogue. The outcome of this stage, like all others, could well be that there is no (immediate) opportunity to pursue. And that is OK! 
In the Storming stage, initial politeness fades, people start to get more into the content and their roles and so start to argue about things that were left unsaid or not realized when they first met. Storming can be fiercer if there is more than one dominant person who wants to be the leader, when there are unclear objectives or motives, and/or when there is some external threat. In this stage, the facilitator (and/or the individual participants) needs to assert their role and help draw out and resolve differences that might otherwise bubble along under the surface, causing continuing team cohesion problems. In this stage it is also relevant to assess the individual goals and see to what extent these are aligned with a potential collective goal. Collaboration and sharing may also start to develop here, continuing into the next stage of developing group norms. At the very least, storming gives a clear indication as to why such rules are needed!

In the Norming phase, after roles and personal conflicts have been sorted out, the focus turns towards identifying and creating the opportunities for shared value creation. Objectives are clarified and planning activities starts. Socially, group rules develop and are refined. Heskett has shown that loyalty to an organization or a group only significantly increases when people are really enthusiastic about it, so that they rate it with 'Excellent' [Heskett (2002)]. From figure 12 it can be concluded that the return on investment in projects aiming to raise the satisfaction level from average (2.5 on a scale of 5) to very good (4.5) is limited in terms of loyalty. Only when people become very satisfied (4.5-5) they become ambassadors for the group or organization! Interestingly enough, most organizations are focusing their client or employee satisfaction efforts exactly in the 'dead' interval 2.5-4.5!

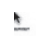

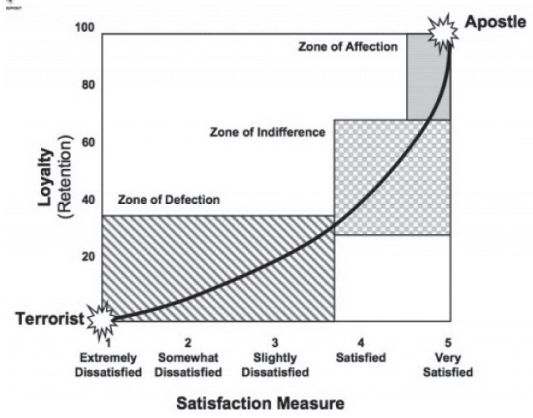

Figure 12: Loyalty to a group and/or organization as function of Satisfaction 
The most important question is therefore: How to shape the group in such a way that the participants become so enthusiastic about it that the engagement becomes exothermic? Mager from the University of Köln has found a number of factors that enthuse people [Mager (2009)]. These include terms like: generosity, belonging, beauty, exclusiveness and flexibility. I think especially the sense of belonging is key, meaning that one experiences the synergistic effects, and feels supported and part of the team. In fact, in spite of their different identities and backgrounds, the individual members can now identify themselves with the team.

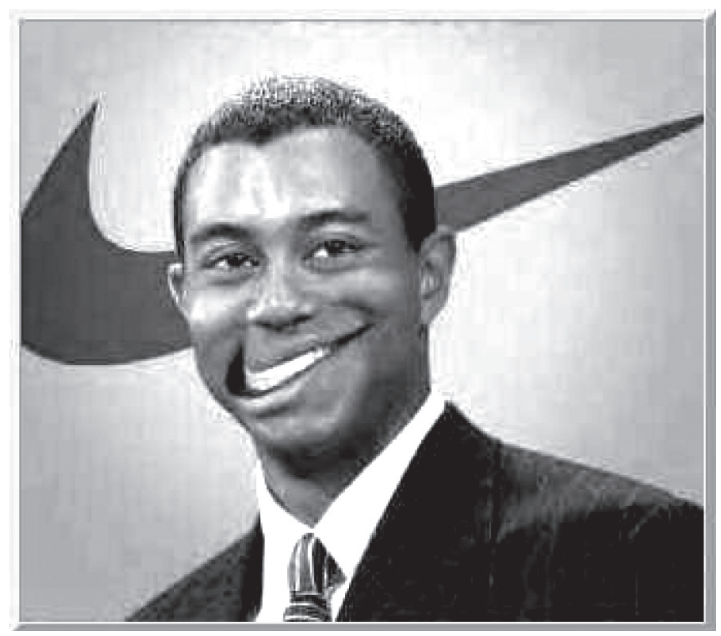

Figure 13: Example of an individual that is quite aligned with the organization. From less formal sources it can be concluded that this person might have an overdeveloped sense of belonging.

Group norms and behaviors may be deliberately developed. This can be by some kind of contractual agreement, from an informal collaboration up, via an alliance, to a formal construct like a Joint Venture or even a complete Merger or Acquistion. This is also the moment to discuss potential issues like sharing Intellectual Property (IP) rights. This is never an easy task, but in the case of Combinatoric Innovation, it requires a careful balancing of interests of sometimes completely different kinds and magnitudes. Nevertheless, the starting point for any venture of this kind should be that everyone agrees that is better to share and have a piece of a big pie than keeping a petite-four to oneself. 
When Performing, the participating members are active fulfilling their tasks and energy comes from the results that are achieved. The process facilitator usually is available for resolving issues and dealing with obstacles. In this stage it is important to check whether everyone is happy with the outcome. Still, also in this stage it might be possible that the intended goals are not reached, which opens the door to a Brilliant Failure as the result. In that case, it should be considered what kind of learning is possible and reflection on the outcome and process (double-loop learning) might generate value as well. Then, it is time for celebration of the effort!

Most often, an end will come to the collaborative journey and a stage of Adjourning sets in. In Combinatoric Innovation we are usually dealing with people with different backgrounds and with different roles and home bases, and who probably showed varying levels of activity and involvement. However, all of them made a contribution based on their intellectual capital, which can be considered as a unique gift to the team! When it is time to end or change the Combinatoric Innovation process in some way, it is important to handle this in the most respectful and intelligent way. Sometimes, team members can be perplexed by the blind refusal to change or contemplate a future without the project. This requires that principles of change management are applied, for example by celebrating the successes of the project or by acknowledging the effort that has been put into the project and appreciate the learning opportunities, which we already discussed in the context of brilliant failures. As with beginnings, rituals can help people cope with the changes of ending.

\section{Managing the Combinatoric Innovation funnel and portfolio}

We introduced Combinatoric Innovation as an extension of Open Innovation in the sense that it starts with making an inventory of Intellectual Capital present in a diverse group and based on this, we start the problem exploring or drafting process. When a candidate objective has been defined, we follow an approach for innovation, which is usually based on stage-gating as depicted in figure 14. This means that the innovation process is divided in a number of phases, each of them concluded by a decision moment.

The ideation phase is quite specific for Combinatoric Innovation. Because of the exploratory nature of this kind of innovation, it is important to do 
the analytics in good quality, but with a sense of reality. It means that a sensible trade-off has to be made between analysis and paralysis. Do not over-invest in the business case. I was recently introduced to the following definition of a business case: "A business case is a collection of lies that we produced to make management decide what we want them to decide."

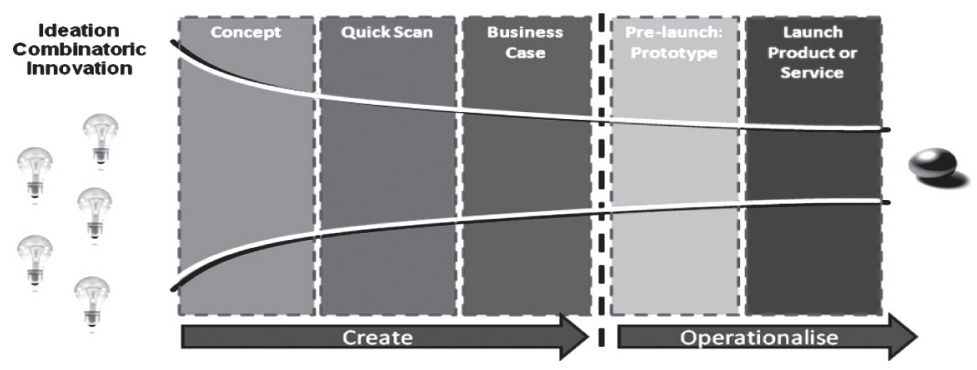

Figure 14: Stage-gate approach for exploratory Combinatoric Innovation

In any case, it makes sense to accept that there cannot be full control over the process and that therefore some 'navigation' is needed. This means that there will always be some degree of uncertainty and that plans might change according to new insights and information. To keep the focus on growing the cake rather than dividing the cake, it is also important to keep the discussion about Intellectual Property to a minimum. Of course, IP rights need to be respected and various forms of (intellectual) input need to be acknowledged. In the contracting phase of the group this needs to be worked out, but the exploratory work in the Combinatoric Innovation process should not be blocked by legal discussions. Where trust is low, transaction costs become high!

The uncertainty and the incompleteness of the business case compared to conventional approaches may necessitate that, in an earlier stage than is usually the case, one might start to develop a prototype and jointly learn from the outcome. It means an experiment or simulation on a representative scale which provides insights that were still lacking in the business case. The conclusion from this prototype might be that it is not worthwhile to pursue, or that the plans need to be fundamentally revisited. Or that the opportunity exceeds the original plans. In both cases, it's a brilliant failure and these should be accepted and the corresponding value should be acknowledged and appreciated! 
An organization or an individual might consider many options for new developments by applying Combinatoric Innovation. Playing the game of identification, combination and application of intellectual capital will give many opportunities for value creation. Of course, one has to focus. But still, it might be possible that multiple bets can be made. In that case, a portfolio approach is appropriate. The risks of a single project can be mitigated by putting it into a portfolio in which other project are present with less risk. Or the portfolio is big enough for many risky projects, as long as the potential upside compensates for the reduced chance of success. Combinatoric Innovation projects might be the 'wild cards' that need to be allowed for. As has been argued before, major breakthroughs often come by surprise or at a time that cannot be predicted because of the complexity of the context. In a portfolio approach, however, one has to assess the risk tolerance of the participants and this has to be communicated, agreed and acted upon. This portfolio approach is compatible with an approach based on RealOption theory. Since Intellectual Capital provides an option on value creation that can be exercised by its owner, which was the essence of the formula for potential value (Exhibit 1), we might expect that essentials of real-option can be applied. One learning in this field, e.g. following from the Black-Scholes equation, is that value of an option increases with increasing spread of the value of the underlying asset [Black and Scholes (1973)]. Combinatoric Innovation provides exactly that: by increasing the number (and size) of potential application areas of the intellectual capital, the spread becomes larger, hence the value of the option!

The best way to summarize the process aspects as discussed above might be to compare them to a 'scrum'. The term 'scrum' has its origins in the sport of rugby and represents close collaboration and a number of short development periods, the 'sprints'. Scrum is being used as a new software-development paradigm with proven advantages, including minimizing risk, quick tangible results, flexibility, engagement, managing complexity, and the ability to freeze the project whilst still having a satisfactory result. From this, it becomes clear that Combinatoric Innovation is closely related to Scrum Methodology. 


\section{Virtual space supporting Combinatoric Innovation}

Without any doubt, developments in ICT have created a boost in intellectual capital development. It started with information becoming better accessible, computations becoming faster and of larger scale, the facilitation of transactions online, and now people and content are connected to people and content. In particular, this last contribution of ICT results in the facilitation of Intellectual Capital discovery and transactions. It is the basis for mechanisms like crowd sourcing that was described earlier in this speech. Online environments for communities, including team rooms, chat boxes, VOIP conversations, shared directories, collaborative workflow support, add value to the activities of these groups. Social networking tools, like Facebook and LinkedIn not only enable a person to manage his or her network, they also offer the possibility for Intellectual Capital discovery resulting from the associations proposed to the user. Algorithms create possible connections, displayed as: 'People You May Know', which are suggestions based on the user's profile, activities and connections. Furthermore, for many users there are millions of potential contacts just one or two steps in the social network. Messages sent via the social networks, including Twitter, might seem irrelevant in most cases, but generate a lot of value by serendipity for those who have the skills to qualify the 'leads' in an efficient way.

The situation will become even more exciting when intelligence is built into the social networking processes. Amazon.com is already doing this through connecting customers to content and products by analyzing the user's activities and transactions in combination with those of other customers. Companies like Autonomy are improving their algorithms for measuring the 'distance' in conceptual spaces which facilitates searching and discovering in a guided way, so that the user is not overwhelmed by the options.

People are increasingly making use of 'The Cloud', which means that they run programs and store information on network servers that can be accessible to others. Intelligent agents could 'trawl' the activities (in particular knowledge transactions) and create intelligence for combinations. This will give a very powerful infrastructure for discovery and combination of Intellectual Capital. It will soon be possible to work in an environment and instantaneously be connected to relevant sources and people. By using the power of imagination and combination, serendipity can do its work and in an emergent new way to create value will be discovered. 
Curiosity and association are important drivers for Combinatoric Innovation and these are exactly the reasons why so many people spend a vast amount of time surfing the Internet. Of course, this has also a downside, also from a social perspective or from a productivity point of view, but I believe next-generation Internet-based tools will soon help us to deal with these negative side effects. In spite of this optimistic view on the value-adding capabilities of virtual spaces, I would like to reiterate a well-known formula:

$\mathbf{N T + O O = E O O : ~ N e w ~ T e c h n o l o g y ~ i n ~ a n ~ O l d ~ O r g a n i z a t i o n ~ r e s u l t s ~ i n ~ a n ~}$ Expensive Old Organization!

This means that we should always use the human being and his/her needs, ambitions and activities as the starting point. It is about 'scalable humanity': Sites like TED.com, Facebook and YouTube.com are very human indeed, while remaining scalable. In the near future, sites might be developed or adjusted that support the Combinatoric Innovation process, which will further increase its relevance and power. The beforementioned crowd sourcing sites, such as InnoCentive, will further develop as well and when they understand the potential of Combinatoric Innovation, they will certainly not only solicit for solutions to problems, but also for problems to solutions! Business models will emergethat make the added value transparent, so that it can be captured and commercialized in a way that companies like Google are mastering to a high degree.

\section{Physical space for Combinatoric Innovation}

It is not always that easy to collaborate or share knowledge. There are geographical boundaries, language barriers, generation gaps, cultural differences, professional specializations and many other obstacles that limit the realization of the full potential of our collective intellectual capital. People only come to a single place if this really adds extra value and when it supports the goals of the individual or the organizations. The question we now need to address is: How can Combinatoric Innovation be boosted by influencing the physical properties of the world surrounding us? In particular, what physical facilities could be developed, geared towards stimulating interdisciplinary, creative and collaborative processes?

Many organizations are looking into the relationship between physical surroundings and creative and future-oriented processes. Future 
Centers in various forms have been developed, as described by Kune [Kune (2008)]. The first Future Center was established in Sweden for the company Skandia, which was established back to 1996. There are now more than 30 future centers in the world, with a relatively large number in the Netherlands, including one for the tax authority, 'De Werf' ('The Shipyard'), see Van der Lugt et. al. (2007). In this speech, I will describe the concept of the No-Boundaries House as a way to create 'Neue Kombinationen' and stimulate serendipity as a core process related to Combinatoric Innovation [Iske and Rinkens (2009)]. A No-Boundaries House is a place where people meet, talk, think, work, enjoy and create together. It is a 'collaboratorium', where people explore new ways forward. In a No-Boundaries House, unexpected encounters occur, new combinations are formed and exchanges of ideas, ideals and insights take place. The physical environment supports the processes that take place. It is important to note that the intangible aspects are as important as the physical properties. The No-boundaries House must have a 'soul'!

Studies and experiences have supported the conjecture that knowledge productivity, (social) innovation and entrepreneurship can be stimulated by developing a physical setting aiming to bring together people with different background and different perspectives. A facility that achieves this, can be considered as a change agent as well as a center for value creation for all stakeholders. Apart from the benefits delivered to the (core) processes of the stakeholders, economic and social value is added to the neighborhood. To increase the success, hospitality-based experiences and concepts should be introduced to maximally engage and attract visitors and participants. The branding of a No-Boundaries House has to be coherent with that of the visitors and their objectives, Hence the motto: It they use it, it will build itself.

Case Study: Dialogues House, Amsterdam: "Making more possible together"

In August 2007, the Management Team of ABN AMRO Bank Netherlands decided to develop the so-called Dialogues House as a place where people meet, collaborate, innovate and develop new business propositions. The Dialogues House is an essential element in building the 'Next-Generation Bank' by providing a window into the future and an outside-in perspective. Situated in the former dealing room of ABN AMRO Bank in Amsterdam, the Dialogues House measures about 2000 square meters. The facility 
offers an inspiring environment for all kinds of meetings around the themes innovation, entrepreneurship, collaboration and sustainability. Though in principle it is an open environment, stimulating people to meet and to start the dialogue, there are plenty of places where people can talk and work in more intimate settings.

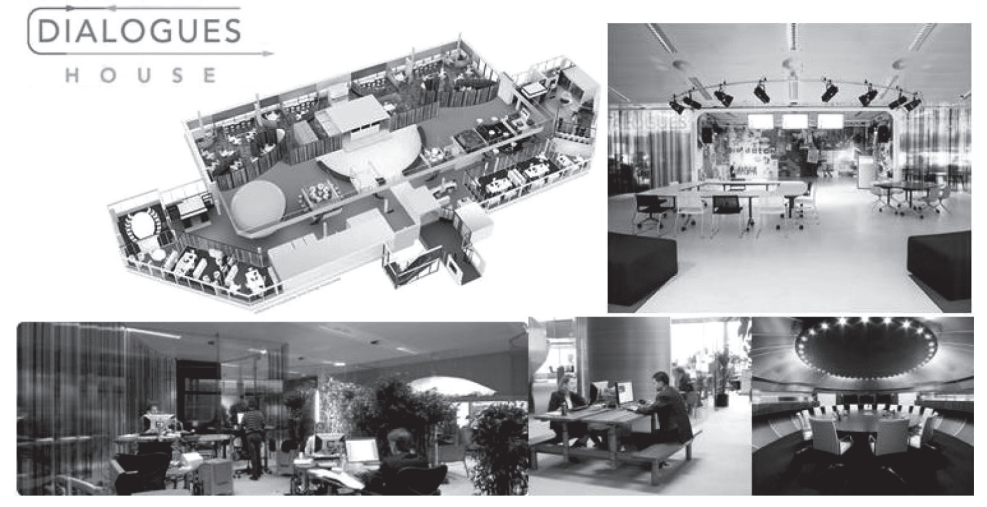

Figure 15. Bird Eye's view of the Dialogues House, Amsterdam

Dialogues House is thus both a theatre and a platform on which eyeopening and inspiring debates, meetings, workshops and presentations are organized by and for people who are committed to enterprise, innovation, cooperation and sustainability. Dialogues House also offers also the opportunity to commercially-minded individuals from both inside and outside ABN AMRO to achieve more together. Business contacts and clients are therefore welcome to attend as well.

Activities with in the Dialogues House are usually freely accessible and are announced on the website www. dialogueshouse.nl. There arealso'permanent' inhabitants, including the Dialogues Incubator and its ventures and other projects and departments related to the themes mentioned above. The support for the Dialogues House has grown consistently since its inception, reflecting the appreciation for the long-term value creation it stands for and the strategy of Combinatoric Innovation based on peopleto-people interaction and collaborative learning.

I believe that for the University Maastricht, the concept of a No-Boundaries House can be very valuable. Universities traditionally have problems with knowledge valorization, in particular because they produce semi- 
products that need to be combined with the know-how, entrepreneurship and distribution channels of commercial partners. The goal of a No-Boundaries House for a university is to promote serendipitous (incidental) learning by being a central meeting place where students, academics and business people, with multidisciplinary backgrounds, are able to engage in dialogue, share experiences and together generate new and innovative ideas for the present and for the next generations. It would be the ideal home for institutions like the Service Science Factory.

Example: I would like to conclude with an illustrative example, in which many aspects of environments for Combinatoric Innovation as described above, play a role.

In 2008, in the Dialogues House a meeting was organized about Open Innovation. Business development managers from a number of organizations met each other, including Philips and ABN AMRO. A few months later, Royal Philips Electronics and ABN AMRO's Dialogues Incubator announced the 'Rationalizer' concept, an emotion sensing system targeted at serious home investors who trade online. It acts as an 'emotion mirror' in which the intensity of the user's feelings is reflected. Research shows that home investors do not act purely rationally: their behavior is influenced by emotions, most notably fear and greed, which can compromise their ability to take an objective, factual stance. This insight led to the Rationalizer concept in which online traders are alerted when it may be wise to take a time-out, wind down and re-consider their actions. Actually, looking at the recent past, one might wonder whether the Rationalizer should not become a business tool for professional traders as well...

The Rationalizer system (www.mirrorofemotion.com) consists of two components - the EmoBracelet and the EmoBowl. The bracelet measures the arousal component of the user's emotion through a galvanic skin response sensor. This arousal level is rendered as a dynamic light pattern on either the EmoBracelet itself or on the EmoBowl. The higher the arousal level, the more intense the dynamic light pattern becomes: the number of elements increases, the speed increases and the color shifts from a soft yellow, via orange, to a deep red. 


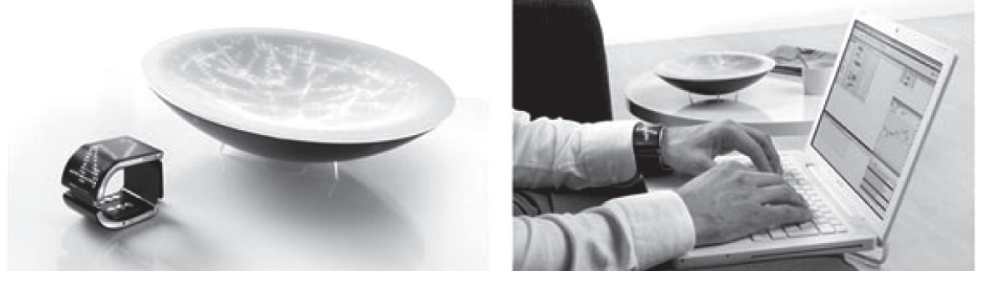

Figure 16 . The Rationalizer, developed via Combinatoric Innovation by Philips and ABN AMRO.

The Rationalizer concept is the result of a joint exploration project by ABN AMRO's Dialogues Incubator and Philips Design. It clearly shows what kind of results can be achieved when two large companies create a stimulating environment for cooperation and open innovation. During the project other crucial parties were involved such as potential endusers, Philips and the Free University (VU) Amsterdam. This cooperation has led to various propositions of which the Rationalizer concept is a first concrete manifestation. In a few years from now you might recognize some of the elements of the Rationalizer concept in products and services we will market by then.

According to the Director Business Development at Philips Design: "Philips Design has been exploring the area of emotion sensing for a number of years and has investigated different application areas, including relaxation and relationship care. In our talks with the people working on the ABN AMRO Dialogues Incubator, we were challenged to apply our competences to another domain, the domain of online trading for home investors. In this joint project we started to tackle this challenge. It proved to be both enjoyable and rewarding, leading to this thought-provoking result."

In this Combinatoric Innovation project ABN AMRO's investment and risk analysis expertise was combined with Philips emotion sensing technology. The concepts underlying the Rationalizer system will be explored further because both partners believe these concepts can add value in a range of areas of application. 


\section{What do you think?}

As Tom Peters recently reiterated a remark from a man called Dave Wheeler, the four most important words in management are: "What do you think?" When we ask, "What do you think?" what we're doing is so much more than just asking a question. For example, when you ask your people "What do you think?",

1. You're giving your people respect (I value what you have to say, which is why l've asked you)

2. You're training your people to be solutions creators (I want you to help solve this so you can do this in the future)

3. You're bringing new ideas into the mix (not giving in to your own biases and prejudices)

4. You're creating buy-in (since people tend to own what they help create)

5. And you're creating relational capital.

Combinatoric Innovation is precisely about that. I would like to invite you to try it yourself. Be curious and be open. Ask questions and look for new combinations. Laugh and you will increase the creativity index!

\section{Looking Forwards}

I have discussed how the ability to create and mobilize intellectual capital is becoming increasingly important in our complex and changing economy, in particular in the service sectors, and the important role that open innovation can play here. We have seen that Combinatoric Innovation is a specific form of open innovation. It is an emergent strategy for value creation based on dialogue, discovery, trial \& error, serendipity and intellectual capital. It requires 'hard' process thinking, including portfolio management, on the one hand, but it is clear that 'soft' elements (with emphasis on the human aspects) are also key. We have seen that one can build capabilities and environments that foster Combinatoric Innovation.

In my work at the University Maastricht, I will focus on creating a better understanding of this phenomenon and on developing scientificallybased approaches to support value creation based on this way of creating, combining and mobilizing intellectual capital. As a board member of the Network of Social Innovation, I have the opportunity to work with colleagues, students and partners to better understand environments that foster Combinatoric Innovation. In addition, I will enjoy working 
with the Service Science Factory, which can be seen as an infrastructure for 'pressure cooking' field research to achieve and study the results of concept development and rapid prototyping, largely based on interdisciplinary collaborative projects. The combination of these engagements will drive my academic work, in which I aim to contribute to the understanding of the holistic picture of content, people, process, ICT and physical facilities for value creation based on Combinatoric Innovation.

The most important driver for Combinatoric Innovation is the ambition for leveraging the value stored in diverse groups, without exactly knowing up front what the result will be. New skills and even new research areas will emerge and I am convinced that multi-disciplinary approaches will be crucial in the identification and understanding of complex systems and problems. Inspiration can of course also come from collaborations with other institutions, including industry. I also want to make my contribution in establishing and leveraging new connections, in developing in new interfaces.

\section{MINDMAP}

An overview of the most relevant concepts and expressions in this speech, as well as their associations, is given in graphical format in figure 17 . 


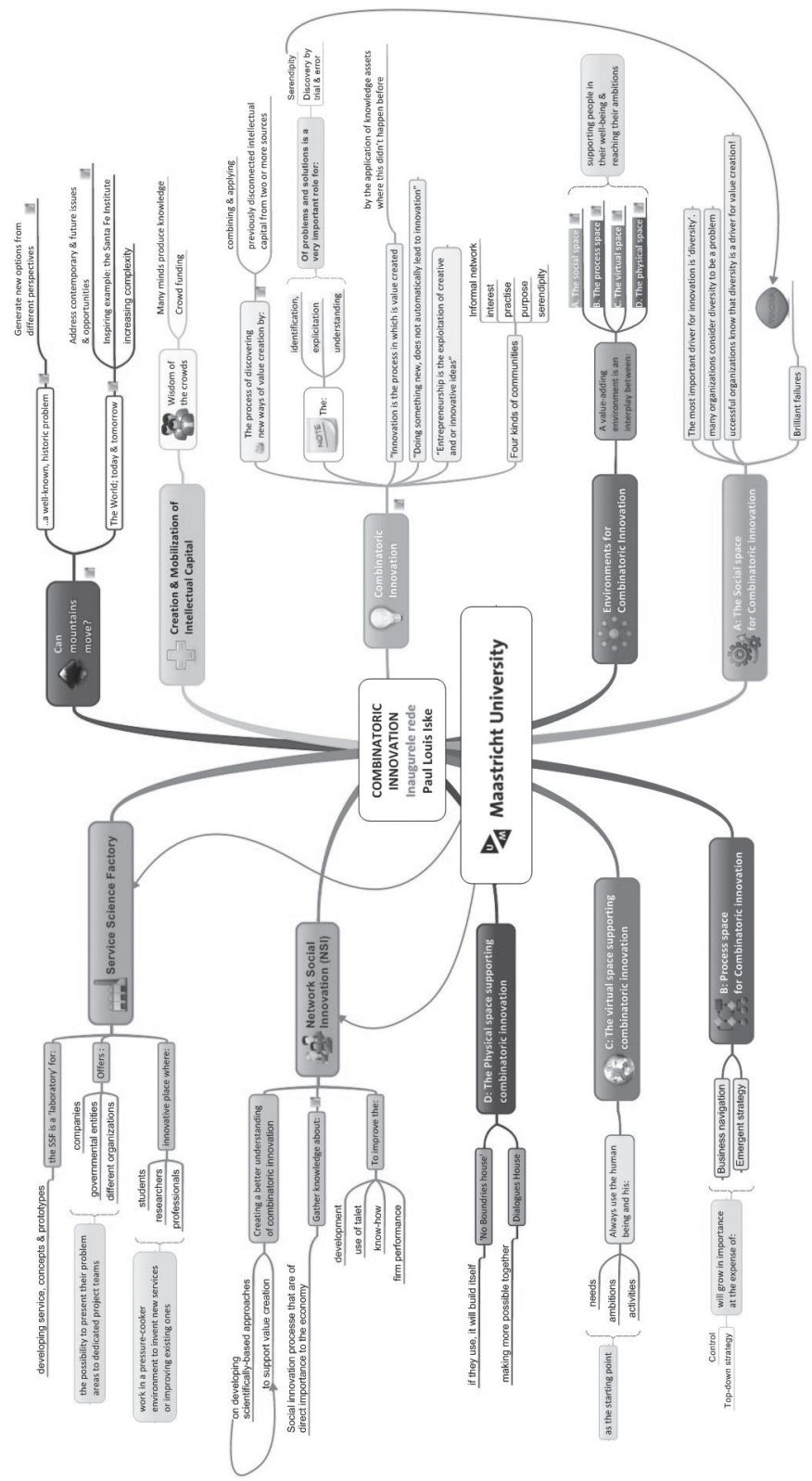

Figure 17. MindMap, containing the most relevant expressions put forward in this speech (produced by World of Minds: www.worldofminds.com) 


\section{Acknowledgements}

Ladies and Gentlemen, it was a great honor for me to address you today. I wanted to share with you some thoughts on how important collective intelligence is to address the challenges and opportunities that we are facing in modern, complex society and how we can utilize the power of Combinatoric Innovation. 'Alone you go faster, together you get further', or as Isaac Newton said: 'If I have seen further than others, it was because I have been standing on the shoulders of giants.' I welcome every attempt to break down the barriers in our mental spaces and I am convinced that the world will greatly benefit from ideas, information and insights that are shared, combined and applied.

I have been working with many organizations in various sectors, in particular ABN AMRO Bank and Shell. This experience has strengthened my vision that people can learn so much from others, as long as they are open-minded and the right conditions are created. I am grateful that I have been given the opportunity to be involved in a dialogue with so many interesting, inspiring and passionate people who share and collaborate to create value.

Personally, I want to thank a number of people who have been with me and supported me on my journey with so many exciting moments of serendipity. With your permission, for this, I would like to use the Dutch language:

Met name de inspirator Jos Lemmink, de duizendpoot Anja Jansen en de andere collega's bij de Service Science Factory, als ook Andries de Grip en overige board members van het Netwerk Sociale Innovatie, maar ook Maurice Olivers: zij zijn allen binnen de School of Business and Economics verantwoordelijk voor mijn aangename landing in de Universiteit Maastricht. Uiteraard zie ik uit naar samenwerking met vele andere collega's bij hopelijk uiteenlopende faculteiten en vakgroepen! Vanaf het begin heb ik het gevoel gehad meer met vrienden dan met collega's te werken. De vele boeiende en waardevolle activiteiten die hier zijn geïnitieerd en waaraan ik mag meewerken hebben mij gesterkt in het gevoel dat de wekelijkse gang over de A2 meer dan de moeite waard is. Mijnheer de Rector Magnificus, collega's: dank voor het vertrouwen en de collegialiteit! Ik verheug mij op de samenwerking in de komende jaren. 
In de afgelopen jaren heb ik heel veel bijzondere mensen ontmoet en hebben velen mijn denken en werken beïnvloed. Sommigen daarvan wil ik expliciet noemen en daarmee mijn erkentenis voor hun bijdragen bevestigen.

Ik ben al sinds 1997 werkzaam bij ABN AMRO in diverse, vaak door mij zelfbedachte functies. In die periode heb ik voortdurend mogen werken aan zaken die te maken hebben met 'naar buiten kijken' en 'de toekomst verkennen'. Ook wanneer de organisatie andere prioriteiten kende, en ik hoef alleen maar te verwijzen naar de voorbije jaren, bleef er ruimte voor mijn werk en denken en dat is best bijzonder te noemen. De mogelijkheid die mij is geboden om mijn werkzaamheden als Chief Dialogues Officer te combineren met het hoogleraarschap, waardeer ik zeer en ik zal er naar streven mijn activiteiten hier in Maastricht ook van waarde te laten zijn voor ABN AMRO.

Mijn collega's binnen het Dialogues House en Dialogues Incubator zijn levende voorbeelden van wat ik vandaag heb proberen te beschrijven. Zij zijn voortdurend op zoek naar nieuwe, innovatie manieren van waardecreatie, waarbij 'ego-boosting' niet aan de orde is, maar samendenken en samenwerken bepalend zijn. In het bijzonder wil ik Jaspar Roos en Hans Cremer bedanken voor hun collegialiteit en hun passie om samen met mij en alle andere collega's Dialogues uit te laten groeien tot een concept waar op vernieuwende en duurzame wijze waarde wordt gecreeerd, waarvoor binnen én buiten ABN AMRO respect voor is ontstaan. Maar ook waardeer ik hun geduld met een manager die veel vertrouwen schenkt, graag coacht en faciliteert, maar soms ook PO zodanig tot een kunst verheven heeft dat grote mentale elasticiteit van hun kant vereist is om niet het spoor bijster te raken. Heleen de Pagter is degene die daarmee nog het meest wordt geconfronteerd en daarvoor veel waardering verdient: zonder haar improviserend vermogen en toegewijdheid had het Dialogues House nooit de klantvriendelijke omgeving kunnen worden die het is en was ik zelf verdwenen in een moeras van dubbele afspraken, niet-werkende IT-systemen en ander chaotisch onheil wat mijn functioneren zeer zou hebben gehinderd.

Ook mijn vrienden bij Conceptisch, Paul en Paul, met assistentie van Martine, zorgen ervoor dat Maastricht mijn tweede thuis is geworden, zowel in zakelijk als persoonlijk opzicht. De onderwerpen waar wij gezamenlijk aan werken en onze passie voor concepten voor waardevolle 
omgevingen zijn onlosmakelijk verbonden met het onderwerp van deze rede. De vriendschappelijke band die we daarbij hebben ontwikkeld, met daarin veel ruimte voor wederzijds respect, vragen en humor, zijn voor mij van grote betekenis.

Natuurlijk bestaat het leven niet alleen uit werken. Weliswaar is het onderscheid tussen werk en privé aan het vervagen, en ik ben daar blij mee, toch is het van belang dat soms ook afstand genomen kan worden. Tijd voor ontspanning, reflectie en inspiratie. Emiel Hanekamp speelt al jaren daarbij een belangrijke rol, door mij niet alleen regelmatig te confronteren met mijn tekortkomingen in tennis, maar zeker ook door onze traditie om jaarlijks met z'n tweeën een week door te brengen in bergachtige streken, van Sicilië tot aan IJsland, maar bovenal in Noorwegen, mijn tweede thuisland.

En uiteraard is daar het thuisfront: de plek waar alles anders is en die ik beschouw als onuitputtelijke bron van inspiratie en energie. Het zal voor mijn gezin niet altijd meevallen om te leven met een mentale ADHD'er. Het feit dat ik nu ook nog eens actief ben geworden in Maastricht betekent dat ik zo nu en dan lange dagen van huis ben. Die ruimte wordt mij geboden en daar ben ik blij mee. Maar bovenal ben ik natuurlijk dankbaar voor de liefde van Hanna en mijn vier kinderen, Roeland, Mirjam, AnneSophie en Louis, waarvan de eerste er helaas niet meer bij kan zijn. Die liefde, die ik overigens ook in ruime mate van mijn ouders heb mogen ontvangen, beschouw ik als verreweg de belangrijkste bron van positieve energie in mijn leven. Ik hoop dat ik daarvan een klein beetje terug kan geven, in de eerste plaats aan mijn dierbaren, maar ook in de vorm van een bescheiden bijdrage aan een betere wereld door het leggen van verbindingen en het helpen creëren en mobiliseren van intellectueel en maatschappelijk kapitaal. Ik geloof oprecht dat het combineren van intellectueel DNA-materiaal ons in staat zal stellen vele oplossingen te vinden voor problemen en nieuwe kansen te scheppen voor waardecreatie, waarbij de weg naar de toekomst vol zit met verrassingen en soms ook briljante mislukkingen.

Ik heb gezegd. 


\section{Literature:}

Bono, Edward de: "Lateral Thinking", Harper \& Row. pp. 300. ISBN 0-14-021978-1 (1970) Chesbrough, Henry, "Open Innovation: The New Imperative for Creating and Profiting from Technology”, Harvard Business School Press (2003)

Christensen, Clayton M. : "The innovator's dilemma : when new technologies cause great firms to fail", Harvard Business Press. ISBN 0-87584-585-1 (1997)

Davenport, Thomas, H.: "The Physical Work Environment and Knowledge Worker Performance", Harvard Business Press (2005)

Florida, Richard: "The rise of the creative class", Basic Books. ISBN 0-465-02477-7 (2002)

Gladwell, Malcolm: "The Tipping Point" Little Brown, ISBN 0-316-31696-2 (2000)

Kim, W. Chan, and Mauborgne, Renée: "Blue Ocean Strategy", Harvard Business School Press. (2005)

Kurzweil, Raymond: “The Singularity is Near", Viking Adult, ISBN 0670033847 (2005)

Prahalad, C.K.: "The Fortune at the Bottom of the Pyramid", Wharton School Publishing (2004) Prahalad, C.K. and Krishnan, M.S.: "The New Age of Innovation", Mc Graw Hill, ISBN 978-007-159828-6 (2008)

Stanley, H.E.: "Introduction to Phase Transitions and Critical Phenomena", Oxford University Press, ISBNo195053168 (1993)

Sunstein, Cass R.: "Infotopia: How Many Minds Produce Knowledge", Oxford University Press, ISBN0195189280 (2006)

Surowiecki, James: "The Wisdom of Crowds: Why the Many Are Smarter Than the Few and How Collective Wisdom Shapes Business, Economies, Societies and Nations", Little, Brown ISBN 0-316-86173-1 (2004)

Taleb, Nassim Nicholas: “The Black Swan”, Random House, ISBN 978-1-4000-6351-2 (2007)

Weggeman, M.C.D.P.: "Kennismanagement, inrichting en besturing van kennisintensieve organisatie”, Scriptum, Schiedam, (1998)

\section{Articles:}

Black, F. and Scholes, M.: (1973). The pricing of options and corporate liabilities, Journal of Political Economy, 81 (3), 637-654.

Edvinsson, L. and Sullivan, P.: "Developing a Model for Managing Intellectual Capital", European Management Journal 14, no. 4 (1996)

European Commission Green Paper: "Entrepreneurship in Europe", [COM (2003) 27 final] (2003) Heskett, J.L.: "Beyond customer loyalty”, Managing Service Quality, Vol. 12 Iss: 6, pp.355-357 (2002)

Iske, P. and Boekhoff, T.: "The value of Knowledge doesn't exist", KM Magazine, Volume 5 , Issue 2 (2001) 
Iske, P.: "Are you challenging your brains?", survey under 1000 people in the Netherlands (2004) Iske, P. \& Boersma, W.: “Connected Brains", Journal of Knowledge Management Volume 9, No. 1 (2005)

Iske, P. \& Rinkens, P.: “No-Boundaries House: Meeting of Minds", proceedings Second Knowledge Cities Summit, Shenzhen (2009)

Iske, P. \& Saint-Onge, H.: "An unconventional Crisis requires and Unconventional Solution", in "Beyond the Crisis", Adjedj Bakas, editor (2009)

Kune, H.: "Future Centers: Environments where Innovations Emerge", METI: Tokyo (2008)

Land, G. and Jarman, B.: "Breaking Point and Beyond", HarperBusiness (San Francisco), 153 (1993) Leadbeater, C., "Innovation: Survival of the Fittest", Accenture Outlook Journal Quarterly 18 (3): 307-343 (2000)

Lugt, R van der \& Janssen, S \& Kuperus S \& Lange E. de: “Future Center 'The Shipyard': Learning from planning, developing, using and refining a creative facility". Creativity and innovation management; 16(1): 66-79 (2007)

Mager, B.: "Enthusiasm in Service? A Research Project on the Design of the Unexpected", paper presented at 'Art and Science of Service V', Waltham USA (2009)

Polanyi, M.: “The Tacit Dimension”, Garden City, New York: Doubleday \& Co. (1966)

Prahalad, C. K. \& Ramaswamy, V.: "Co-creation experiences: The next practice in value creation." Journal of Interactive Marketing 18(3): 5-14 (2004).

Roberts, H: "The Control of Intangibles in the Knowledge-intensive Firm”, Paper presented at the 22nd Annual Conference of the European Accounting Association, Bordeaux (1999)

Tuckman, B.: "Developmental sequence in small groups", Psychological Bulletin 63 (6): 384-99 (1965)

\section{Websites:}

Creative Industry SOFA: http://www.creativeindustrysofa.com/

Dialogues House: www.dialogueshouse.nl

Innocentive: www.innocentive.com

Institute of Brilliant Failures: www.brilliantfailures.com

LEGO DESIGNbyME: http://designbyme.lego.com/en-us/default.aspx

Network Social Innovation: www.networksocialinnovation.nl

Rationalizer: www.mirrorofemotion.com

Santa Fe Institute: http://www.santafe.edu/

Service Science Factory: www.servicesciencefactory.nl

The four most important words according to Tom Peters: http://www.tompeters.com/ blogs/toms_videos/docs/Leadership_4_Most_Important_Words.pdf

World Food Programme: http://www.movingtheworld.org/ 
